\title{
Climate Change Impacts on Sediment Yield and Debris-Flow Activity in an Alpine Catchment
}

\author{
J. Hirschberg ${ }^{1,2}$, S. Fatichi ${ }^{3}$, G.L. Bennett ${ }^{4}$, B.W. McArdell ${ }^{1}$, N. Peleg ${ }^{2}$, S.N. \\ Lane $^{5}$, F. Schlunegger ${ }^{6}$, and P. Molnar ${ }^{2}$ \\ ${ }^{1}$ WSL, Swiss Federal Institute for Forest, Snow and Landscape Research, Birmensdorf, Switzerland \\ ${ }^{2}$ Institute of Environmental Engineering, ETH Zurich, Zurich, Switzerland \\ ${ }^{3}$ Department of Civil and Environmental Engineering, National University of Singapore, Singapore \\ ${ }^{4}$ Geography, University of Exeter, Exeter, United Kingdom \\ ${ }^{5}$ Institute of Earth Surface Dynamics, University of Lausanne, Lausanne, Switzerland \\ ${ }^{6}$ Institute of Geological Sciences, University of Bern, Bern, Switzerland
}

\section{Key Points:}

- A chain of climate-hydrology-geomorphology models is used to quantify possible impacts of climate change on sediment yields and debris flows

- Future climate conditions favour increases in sediment transport capacity but a reduction in sediment supply limits debris-flow activity

- A reduction in sediment yield of $-48 \%$ is expected by 2085 ; predicted reductions in nearer future are within present-day natural variability

Corresponding author: J. Hirschberg, jacob.hirschberg@wsl.ch

This article has been accepted for publication and undergone full peer review but has not been through the copyediting, typesetting, pagination and prodfreading process, which may lead to differences between this version and the Version of Record. Please cite this article as doi: 10.1029/2020JF005739. 


\begin{abstract}
Climate change impacts on sediment production and transfer processes on hillslopes and through channels are governed by possible changes in precipitation, runoff and air temperature. These hydrological and geomorphological impacts are difficult to predict in temperature-sensitive Alpine environments. In this work, we combined a stochastic weather generator model with the most current climate change projections to feed a hillslope-channel sediment cascade model for a major debris-flow system in the Swiss Alps (the Illgraben). This allowed us to quantify climate change impacts and their uncertainties on sediment yield and the number of debris flows at hourly temporal resolution. We show that projected changes in precipitation and air temperature lead to a reduction in both sediment yield $(-48 \%)$ and debris-flow occurrence $(-23 \%)$. This change is caused by a decrease in sediment supply from the hillslope, which is driven by frostweathering. Additionally, we conduct model experiments that show the sensitivity of projected changes in sediment yield and debris-flow hazard to basin elevation, with important implications for assessing natural hazards and risks in mountain environments. Future changes in hydrological and sediment fluxes are characterized by high uncertainty, mainly due to irreducible internal climate variability. Therefore, this stochastic uncertainty needs to be considered in climate change impact assessments for geomorphic systems.
\end{abstract}

\title{
1 Introduction
}

Climate has an important moderating effect on erosion and mass-wasting processes, shaping basins and river networks, and determining sediment yield at both the event and geological timescales (Perron, 2017). Studies of climate change impacts on Alpine mass movements have led to the general expectation of increases in frequencies and magnitudes of mass movements (IPCC, 2012). On the one hand, such a change is expected because permafrost warming and thawing and glacier retreat are likely to lead to an increase in unstable sediments, which can be mobilized as debris flows by intense convective rainfall (Harris et al., 2009; Fischer et al., 2013; Giorgi et al., 2016; Ban et al., 2015, 2018; Turkington et al., 2016; Coe et al., 2018) and expose downstream communities to mass movement risk (Gariano \& Guzzetti, 2016). On the other hand, it has also been argued that the number of days favourable for debris-flow triggering will potentially decrease in some regions, especially in summer (Jomelli et al., 2009; Stoffel et al., 2014). This is corroborated by the latest climate change scenarios projecting drier summers over the Alps (Rajczak et al., 2013). However, for large parts of the world quantifying the mass movement response to climate change remains a difficult task (Gariano \& Guzzetti, 2016).

Modelling sediment transport and storage is challenging because of complex relationships between climatic forcing, hydrological connectivity, sediment production, and the different geomorphic thresholds involved (e.g. Peizhen et al., 2001; Phillips, 2003; Lancaster \& Casebeer, 2007; Temme et al., 2009; Coulthard \& Van De Wiel, 2013; Pelletier, 2015; Campforts et al., 2020). Modelling experiments examining the sensitivity of basin sediment yield to climate change cover a large range of process scales and environments, particularly in relation to landscape evolution (e.g. Tucker \& Slingerland, 1997; Istanbulluoglu, 2009; Coulthard et al., 2012; Perron, 2017). There have also been investigations of the impacts of climate variability on catchments and smaller hillslope scales (e.g. Mullan et al., 2012; Francipane et al., 2015; Shrestha \& Wang, 2018; Tsuruta et al., 2019; Peleg, Skinner, et al., 2020; Battista et al., 2020), and on the sensitivity of sediment yield to land use and land cover change (e.g. Molnar et al., 2006; Coulthard \& Van De Wiel, 2017; Yetemen et al., 2019). The commonality of these studies is that the simulated variability in sediment yield is often very large. This can be explained by sensitivity to initial conditions, model structure and parameters, and the type and magnitude of change in driving conditions (e.g Temme et al., 2009; Coulthard

This article is protected by copyright. All rights reserved. 
\& Van De Wiel, 2013; Hancock et al., 2016; Skinner et al., 2018), but it is also likely to be an inherent property of the geomorphic system response itself.

A typical problem in most modelling studies is that the models or the climate inputs to drive the models use spatio-temporal resolutions that are too coarse to represent adequately geomorphic responses to extreme events (Coulthard et al., 2012; Coulthard \& Skinner, 2016). Notable exceptions are the studies of Coulthard et al. (2012) and Francipane et al. (2015) who consider finer temporal (hourly) and spatial resolutions (10-50 m). However, these and many other models with a strong focus on fluvial erosion, are not designed for Alpine basins where the sediment yield is strongly controlled by hillslope processes and debris-flow torrents. In the context of climate change, a model for assessing sediment yields in Alpine torrents needs to focus on the hillslope sediment production and transfer by mass movements as well as on the hydrological triggering of hillslope failures and debris flows, and changes therein.

In climate change impact studies large parts of the uncertainties stem from the climate projections and quantifying the main sources of uncertainty is important for understanding how to decrease total uncertainty (Deser et al., 2012). Total climate change uncertainty can be partitioned into scenario uncertainty due to uncertainty in future greenhouse gas emissions, model uncertainty due to different responses to radiative forcings in different climate models, and internal climate variability, the stochastic uncertainty in climate, arising even without radiative forcing and which will remain irreducible (Hawkins \& Sutton, 2009). Studies have pointed to the important role of uncertainty partitioning for climate change predictions (e.g. Deser et al., 2012; Fatichi et al., 2016; Lehner et al., 2020), but have seldom been considered in the geomorphic context with few exceptions (Coulthard et al., 2012; Francipane et al., 2015; Kim et al., 2016b).

Here, we use a modelling framework to explore the impacts of the latest climate change scenarios on a geomorphic system where the processes of sediment production and transport are driven by precipitation, runoff, freezing conditions and snow cover dynamics. We focus upon a geomorphologically active Alpine basin (Illgraben, Switzerland), which is fed by shallow landslides and deeper seated rock slides on hillslopes (Bennett et al., 2012) and results in frequent debris flows in the channels (Hürlimann et al., 2003). The study addresses the following research questions:

1. What is the change and uncertainty in predicted sediment yield for a future climate and does it originate from projected changes in precipitation or temperature (or both)? We explicitly quantify sources of uncertainty: from climate model uncertainty to irreducible internal climate variability (stochastic uncertainty).

2. From sediment production areas to catchment yield, how is the climate change signal reflected in hillslope sediment production processes (frost-weathering) and in sediment discharge events (debris flows)? This question directly addresses the role of sediment supply and storage in the hillslope-channel system in determining the size of sediment discharge events.

3. Are climate change impacts on sediment production and yield consistent across different elevations? The answer to this question is critical for assessing the elevation sensitivity of climate change signals in geomorphic processes and for the generalizations of results to other mountainous basins.

These questions are addressed using a combination of hourly climatic data simulated with the AWE-GEN weather generator (Fatichi et al., 2011) and trained to reproduce current and future climates from the latest climate change scenarios for Switzerland (CH2018, 2018). These climatic data are fed to a sediment cascade model (SedCas) of hillslopechannel storage and transfer processes in the Illgraben (Bennett et al., 2014). 


\section{Study Site}

The Illgraben is one of the most active debris-flow catchments in the Swiss Alps (Figure 1). Despite its small size $\left(4.83 \mathrm{~km}^{2}\right)$, debris flows deliver on the order of $\sim 100$ tons of sediment annually into the Rhône Valley, building up an alluvial fan and developing a braided river morphology in the Rhône river for over $6 \mathrm{~km}$ downstream (e.g. Schlunegger et al., 2009; Franke et al., 2015). The elevation ranges from $886 \mathrm{~m}$ a.s.l. at the base of the fan to a maximum of $2645 \mathrm{~m}$ a.s.l. below the Illhorn. The eastern Illbach catchment is of similar size and used to drain into the same channel at the top of the fan, but its headwaters are hydrologically disconnected due to the Illsee dam. The Illbach channel is densely vegetated and enters the channel as a hanging valley. Therefore, the Illbach catchment is considered to be geomorphologically much less active than the Illgraben and was excluded in this study. The Illgraben catchment has a temperate-humid climate and a precipitation gradient from 800 to $1000 \mathrm{~mm}$ per year and mean annual air temperature of about $6^{\circ} \mathrm{C}$ at the Illgraben mean basin elevation (1600 m a.s.l.) (Hydrological Atlas of Switzerland, 2015).

Hillslope erosion by landsliding and rockfalls in the sediment producing part of the Illgraben results in mean erosion rates of $0.39 \pm 0.03 \mathrm{~m} / \mathrm{y}$ (Bennett et al., 2012). In total, a sum of $\sim 2500$ slope failures have been identified for the time period between 1986 and 2005. The majority were small failures removing the upper weathered layer of the slope, but large less-frequent and deep-seated failures produced almost $99 \%$ of the total eroded volume (Bennett et al., 2012). A typical acceleration of hillslope activity is observed in spring due to high subsurface moisture and freeze-thaw cycles (Berger et al., 2011b; Caduff et al., 2014) and sediment accumulation at the toe of slopes is periodically removed by floods and debris flows in the snow-free period (Bennett et al., 2013).

Debris-flow activity has been monitored by the Swiss Federal Institute for Forest, Snow and Landscape Research (WSL) since 2000. The observation station consists of geophones placed along the channel to determine flow speed, laser and radar sensors to measure flow depth (Hürlimann et al., 2003), and a force plate to measure flow density and shear stress since 2004 (McArdell et al., 2007). A separate early warning system for the community with geophone and radar sensors has also provided data since 2007 (Badoux et al., 2009). On average, about 3 to 4 large debris flows $\left(>3000 \mathrm{~m}^{3}\right)$ per year have been recorded at the outlet, some of which have volumes in excess of $10^{5} \mathrm{~m}^{3}$ (Schürch et al., 2011). Smaller debris flows and hyper-concentrated floods cannot be reliably measured and are not recorded.

The Illgraben can be conveniently thought of as a sediment cascade, consisting of hillslopes which produce sediment by landslides, and the channel system which collects hillslope-derived sediment and periodically releases it in sediment-laden floods and debris flows, similar to the concept of Benda and Dunne (1997a, 1997b). This conceptualization into a hillslopechannel cascade while accounting for the hydrology and runoff formation on a daily basis was used by Bennett et al. (2014) to develop the SedCas model for the Illgraben system.

\section{Methods}

\subsection{Study Design}

This study combines two models: climate variables generated by the AWE-GEN stochastic weather generator model (Fatichi et al., 2011) are used as inputs into the SedCas sediment cascade model (Bennett et al., 2014). SedCas and AWE-GEN are calibrated using observed hourly climate data (precipitation, near surface air temperature at $2 \mathrm{~m}$, referred to as temperature hereafter, and shortwave solar radiation). AWE-GEN is re-parameterized to simulate future climates using the Factors of Change method (FC,

This article is protected by copyright. All rights reserved. 


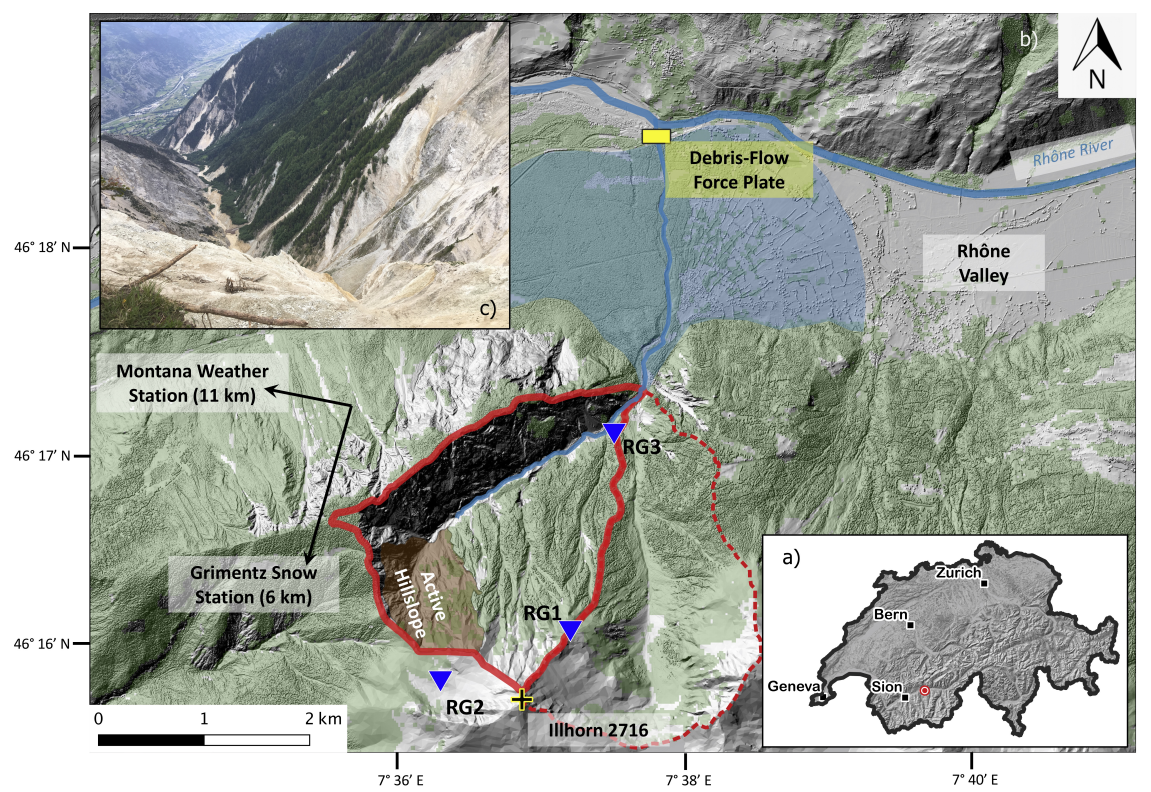

Figure 1. (a) The Illgraben study area is located in southwestern Switzerland. (b) The catchment elevation (solid red line) ranges from 886 at its outlet to $2645 \mathrm{~m}$ a.s.l just below the Illhorn. The most active part (Active Hillslope) of the catchment was the study slope for the hillslope failure assessment by Bennett et al. (2012). Vegetation (green) covers $56 \%$ of the catchment. Rain gauges (RG) have been in operation since 2001 and the debris-flow force measurement plate, which is located in the channel at the end of the fan (blue shading), since 2003. The Illbach catchment (dashed red) is geomorphologically disconnected. Distances and directions to the Montana weather station and the Grimentz snow station are indicated. (c)The photo is taken from the crest looking down along the Illgraben channel and also shows parts of the active hillslope, the fan and the Rhône Valley (photo by M. Wenner, WSL, 2019).

This article is protected by copyright. All rights reserved. 


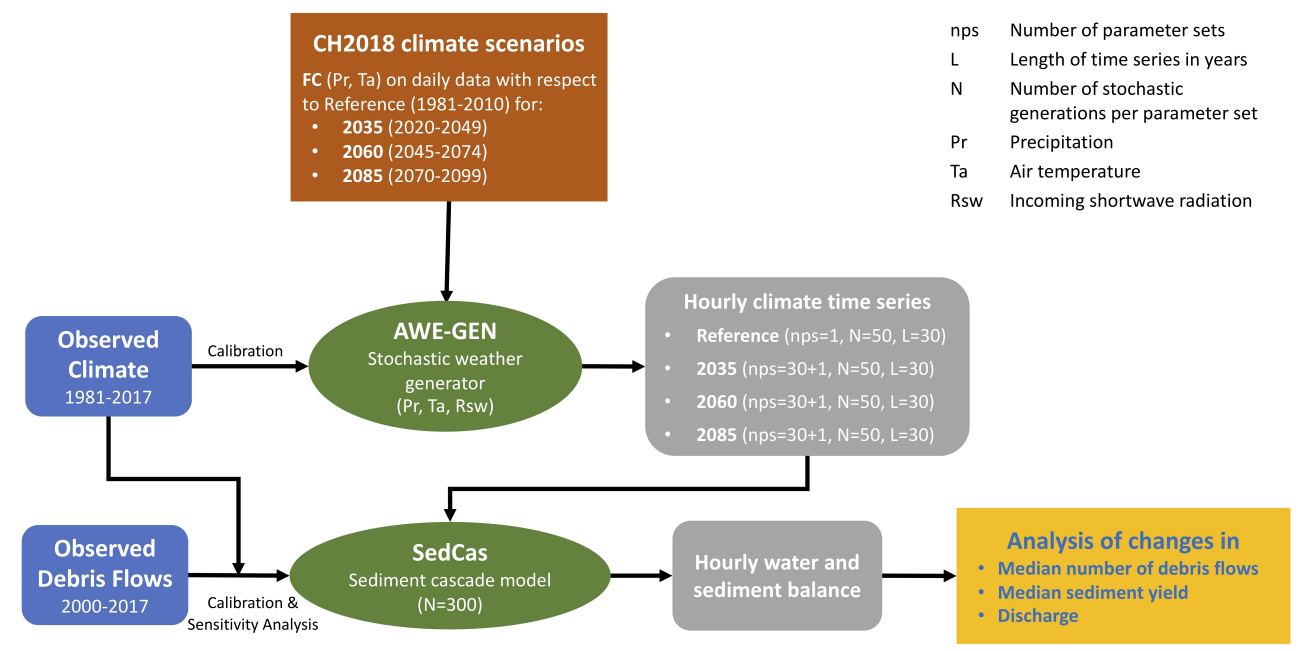

Figure 2. Flowchart of the methods: the two central modelling elements (green) are the models for generating stochastic climate (AWE-GEN) and the model for simulating the hydrology and sediment fluxes (SedCas). The data sources are Factors of Change (FC) derived from CH2018 climate scenarios (red) and the observed climate and debris-flow data (blue), which are used to calibrate both AWE-GEN and SedCas independently. Four scenarios are investigated one reference scenario, representing the recent climate when debris-flow observations were made, and three future climate periods (grey). These are used to drive the SedCas model and analyze changes in sediment yield and debris-flow statistics (yellow).

see Fatichi et al., 2013) applied to the official Swiss CH2018 climate scenarios. FC are computed for key climate statistics between current and future climates and implements them in the weather generator for three future periods in the $21^{\text {st }}$ century to simulate ensembles of future climate conditions. Finally, these ensembles are used as forcing in SedCas and allow us to quantify climate change impacts on sediment yield and debrisflow activity and their uncertainty (Figure 2).

\subsection{Data}

\subsubsection{Debris-Flow Observations and Landslide Inventory}

The Illgraben debris-flow monitoring station was installed in 2000 and includes a debris-flow force plate since 2003 (McArdell et al., 2007), which permits estimation of bulk density and mass transport from the catchment (Schlunegger et al., 2009). A total of 75 debris flows were recorded between 2000 and 2017 with bulk volumes ranging from 2000 to more than $10^{5} \mathrm{~m}^{3}$ (McArdell \& Hirschberg, 2020). The debris-flow force plate is situated just before the confluence of the Illbach with the Rhône river under the bridge of the main road. This location is relatively far from the debris-flow initiation area $(\sim 5 \mathrm{~km})$ and erosion and deposition along the channel on the fan has been observed (Schürch et al., 2011; Berger et al., 2011a; de Haas et al., 2020). We assume this erosion-deposition effect to be negligible compared to total debris-flow volumes and over longer time scales (years) because the channel is stabilized by many check dams.

This article is protected by copyright. All rights reserved. 
Bennett et al. (2012) analyzed slope erosion on the active hillslope (Figure 1) from 1963 to 2005 using digital photogrammetry. The slope failures $(\sim 2500)$ follow a magnitudefrequency distribution which is typical for landslides and characterized by a rollover and a power-law tail, which is used to stochastically sample the magnitude of hillslope failures in SedCas when climatic landslide triggering conditions are met.

\subsubsection{Observed Climate Data}

Three meteorological stations within the Illgraben catchment (Figure 1) have records of precipitation (liquid only) and temperature. All rain gauges have recorded data since the year 2001. Temperature data from these stations were used to calculate monthly lapse rates for the extrapolation of the temperature data to the basin mean elevation (as in Bennett et al., 2014). Measurements of hourly precipitation, temperature and incoming solar radiation are taken from the Swiss Meteorological Office (MeteoSwiss) data collected at the Montana station because in contrast to the rain gauges it also records solid precipitation and it is considered to be more reliable. The Montana weather station is located $11 \mathrm{~km}$ to the northwest (Figure 1) and has been recording automatically since 1981. To compensate for the fact that the weather station is outside the catchment, we scale the hourly precipitation records to match the daily totals in the study area provided by MeteoSwiss in the form of 1x1 km gridded data (RhiresD). From RhiresD we extracted the cells covering the study area and calculated a mean areal precipitation for each day. Snow depth is taken from Grimentz (Figure 1), a station $6 \mathrm{~km}$ south at similar elevation, for the calibration period of 2000 to 2017. Cloud cover information was acquired from the European Centre for MediumRange Weather Forecasts Reanalysis Fifth generation (ERA5; Copernicus Climate Change Service (C3S), 2017; Hersbach et al., 2018).

\subsubsection{CH2018: Swiss Climate Change Scenarios}

The CH2018 dataset provides the most up-to-date climate change information for climate impact assessments in Switzerland. CH2018 climate scenarios were developed by the National Center for Climate Services (NCCS) and provide climate change projections based on the EURO-CORDEX ensemble of climate simulations with Regional Climate Models (RCMs). Direct RCM outputs are biased for Alpine regions because with a maximal resolution of $12.5 \mathrm{~km}$ the topographical and climatological heterogeneities are not sufficiently well resolved. Therefore, CH2018 RCM simulations include a statistical downscaling to represent the local scale. This is achieved by assuming stationary (i.e. time-invariant) relationships between RCM runs for current climate and observations, and applying quantile mapping to match the distributions of observed and simulated climate variables. Quantile mapping was applied both to climate stations and a $2 \mathrm{~km}$ grid on the daily scale in Switzerland, for an ensemble of climate model chains (i.e. combinations of GCMs and RCMs) and for three Representative Concentration Pathways, which lead to an added radiative forcing of $2.6,4.5$ and $8.5 \mathrm{~W} \mathrm{~m}^{-2}$ at the end of the $21^{\text {st }}$ century (RCP2.6, RCP4.5, RCP8.5). While quantile mapping is an oftenused method for bias-correction in climate scenarios, it contains limitations which are important for applications such as the assumption of stationarity in the model biases, and large uncertainties in the extremes, i.e. for high and low quantiles. For more details the reader is referred to the $\mathrm{CH} 2018$ technical report $(\mathrm{CH} 2018,2018)$. Weather generators in combination with $\mathrm{CH} 2018$ produce stochastic time series of climate variables to investigate internal climate variability. These climate variables can be generated with physical consistency between them and at sub-daily temporal resolution (see Section 3.4).

This article is protected by copyright. All rights reserved. 


\subsection{Sediment Cascade Model (SedCas)}

SedCas was developed by Bennett et al. (2014) and consists of two connected sediment storage reservoirs consisting of hillslopes and channels in the Illgraben where sediment transfer is driven by hydrological processes lumped in space at the basin scale. Sediment is produced by shallow landslides and rockfalls, and is delivered into the hillslope and channel reservoirs from where it is evacuated by debris flows and sedimentladen floods. Sediment transport events are triggered by runoff which is simulated by solving the water balance over the basin including the main hydrological processes. The actual transported volumes are conditioned by the availability of sediment in channel storage at the time of triggering. SedCas is intended to be used for probabilistic predictions and not to reproduce specific events. This reflects the observation that the triggering of landsliding and the weather conditions are stochastic forcings. Although this spatially-lumped and conceptual model does not allow to investigate sediment production and transfer processes in a detailed and spatially explicit way, it is important to retain the parsimonious nature of SedCas, because the focus on the critical processes enables the cause-effect tracing at the catchment scale (see also model of Benda \& Dunne, 1997a, 1997b; Lu et al., 2005). For this study, we have improved SedCas in the following aspects:

- temporal resolution is increased from daily to hourly to improve representation of processes at the sub-daily scale such as extreme precipitation, evapotranspiration, snow accumulation and melt, and triggering conditions of debris flows

- the water balance is solved separately for vegetated ( $56 \%$ of the catchment area) and non-vegetated (44\%) hydrological response units (HRU) separately to better consider effects related to water storage and runoff generation

- fluvial bedload transport for steady-state discharge below the critical debris-flow triggering threshold $\left(Q<Q_{d f}\right)$ is introduced for sediment-laden floods, which follows a rating curve for a better representation of the sediment balance

These changes involve new model variables and parameters to those used in the original model and a need for re-calibration. We employed a Monte Carlo modelling framework for calibration purposes, in particular to estimate model parameter distributions and to conduct a model sensitivity analysis. This procedure is described in more detail in Section 3.3.3. In the following we only summarize the most relevant processes considered in the model (Sections 3.3.1 and 3.3.2). For more model details the reader is referred to Bennett et al. (2014).

\subsubsection{Hydrological Processes}

The hydrological module in SedCas solves the water balance at the basin scale for two hydrological response units (HRU) representing the vegetated $(v)$ and the nonvegetated $(n v)$ parts of the catchment, respectively. Hydrological processes of precipitation, snow accumulation and melt, evapotranspiration, and runoff generation, are solved with conceptual methods averaged over the HRU area. A schematic model structure can be found in the supplementary information (Figure S1). Change in water storage $S_{w}$ in $\mathrm{mm}$ in the basin is solved at the hourly time step:

$$
\frac{d S_{w}}{d t}=R(t)+M(t)-E(t)-Q(t)
$$

where $R(t)$ is rainfall, $M(t)$ is snowmelt, $E(t)$ is actual evapotranspiration and $Q(t)$ is runoff, all at time $t$ and in $\mathrm{mm} \mathrm{h}^{-1}$.

In the case of precipitation, it occurs as rainfall when $T(t)>T_{s a}$, where $T(t)$ is the mean hourly air temperature in ${ }^{\circ} \mathrm{C}$ and $T_{s a}$ is the temperature threshold for snow accumulation. When $T(t) \leq T_{s a}$ precipitation is accumulated in the snowpack as snow

This article is protected by copyright. All rights reserved. 
water equivalent. $M(t)$ is simulated with the degree-day method applied to hourly data with a rate equal to $M(t)=m\left(T(t)-T_{s m}\right)$ when $T(t)>T_{s m}$, where $m$ is the hourly melt factor in $\mathrm{mm} \mathrm{h}^{-1}{ }^{\circ} \mathrm{C}^{-1}$ and $T_{s m}$ is the temperature threshold for snowmelt.

$E(t)$ is computed as a fraction of potential evapotranspiration $P E T(t), E(t)=$ $\gamma P E T(t)$, with $P E T(t)$ computed with the Priestley-Taylor method (Priestley \& Taylor, 1972), and with the dimensionless efficiency parameter $\gamma(t)=1-\exp \left(-\alpha \frac{S_{w}(t)}{S_{w}^{*}}\right)$ related to the basin water storage. Priestley-Taylor requires reference albedo values which were taken from Brutsaert (2005).

Each HRU can have a user-defined number $n$ of vertically connected water storage reservoirs with capacity $S_{w, i}^{* h}$ in $\mathrm{mm}$, where $h$ indicates the HRU and $i$ the reservoir in the $\operatorname{HRU}(1,2, \ldots, n)$. In this study, $n$ equals 1 for the non-vegetated and 2 for the vegetated HRU. The total water storage capacity is given by the sum of the vertically stacked water storage capacities. Liquid water from rainfall or snowmelt are inputs to the top reservoir $(i=1)$ (Eq. 1). Water can percolate $\left(Q_{s s, i}^{h}\right.$ in $\left.\mathrm{mm} \mathrm{h}^{-1}\right)$ to deeper unsaturated reservoirs following the linear reservoir concept, and finally leaves the HRU as subsurface flow from the deepest reservoir. Surface runoff $Q_{s}^{h}$ in $\mathrm{mm} \mathrm{h}^{-1}$, can be generated only from the shallow top soil layer $(i=1)$ by two mechanisms; either (1) as infiltration excess runoff if only the shallow reservoir is saturated and rainfall and/or snowmelt rate exceeds the percolation rate to the deeper reservoir, or (2) by saturation excess runoff if deeper layers are also saturated. These processes can be expressed as follows:

$$
\begin{gathered}
Q_{s s, i}^{h}(t)= \begin{cases}\frac{1}{k_{i}^{h}} \cdot S_{w, i}^{h}(t), & \text { if } \quad S_{w, i+1}^{h}(t)<S_{w, i+1}^{* h} \quad \text { or } \quad i=n \\
0, & \text { if } \quad S_{w, i+1}^{h}(t)=S_{w, i+1}^{* h,}\end{cases} \\
Q_{s}^{h}(t)= \begin{cases}0, & \text { if } \quad S_{w, 1}^{h}(t) \leq S_{w, 1}^{* h} \\
S_{w, 1}^{h}(t)-S_{w, 1}^{* h}, & \text { if } \quad S_{w, 1}^{h}(t)>S_{w, 1}^{* h}\end{cases}
\end{gathered}
$$

where the linear reservoir parameter $k_{i}^{h}$ in $\mathrm{h}$ represents the mean residence time of water in the corresponding reservoir (in saturated conditions). The flows of the respective HRUs are added in the channel where also sediment is stored and mobilized. Surface runoff $Q_{s}$ is the hydrological forcing on hillslopes, rills, gullies and first-order channels that mobilizes sediments and can trigger debris flows. The water storage is controlled by climate and soil layer (or reservoir) storage capacities and residence times.

In the non-vegetated HRU we define just one reservoir, where $S_{w}^{* n v}$ represents the available storage volume in weathered and fractured bedrock, scree slopes, hillslope debris and alluvial deposits in the catchment. In the vegetated HRU we consider two soil layers (reservoirs), where $S_{w, 1}^{* v}$ represents interception and soil water storage in the shallow top soil layer, and $S_{w, 2}^{* v}$ is the deeper soil water storage capacity given by porosity and soil thickness in the deeper layer.

\subsubsection{Sediment Production and Transfer}

Sediment input into the hillslope-channel reservoir system in SedCas is produced by frost-weathering, triggering landslides and rockfalls from hillslopes in the headwater subbasins (Berger et al., 2011b; Bennett et al., 2014; Caduff et al., 2014). The hillslope erosion rate $E_{h}(t)$ is given by a landslide volume which is drawn from a data-derived probability distribution (Bennett et al., 2012). Bennett et al. (2013) show that landslides are most likely thermally triggered by frost-cracking on days when there is low insulating snow cover in the basin: snow cover $s<s_{l s}$ and mean daily temperature $\bar{T} \leq 0^{\circ} \mathrm{C}$. The same landslide triggering mechanism has also been demonstrated for other Alpine basins (e.g. Bardou \& Delaloye, 2004; Rengers et al., 2020). In addition to these large slope failures which happen on some days, small landslides are generated more frequently using a log-normal probability distribution fitted to the data from a background erosion rate (Bennett et al., 2014). The exact number of small landslides is given by a ra- 
tio of small to large landslides (equal to 3.4) observed by Bennett et al. (2012) and their timing is independent and sampled from an exponential distribution. The frequency of the large landslides is matched (calibrated) to reproduce the long-term mean annual hillslope erosion rate in the Illgraben $\hat{E}_{h}=0.39 \pm 0.03 \mathrm{~m} \mathrm{y}^{-1}$ from a sediment producing area at the head of the catchment (Bennett et al., 2012). Landslides deliver sediment to the hillslope reservoir as a daily total volume in the middle of the day (noon). The thermally conditioned timing means that this results in seasonal refilling of sediment stores in late autumn and early spring and their emptying by runoff triggered by intense rainfall in summer as has been observed by Berger et al. (2011b).

The hillslope reservoir in SedCas stores a fraction of the landslide volume in debris cones and landslide deposits at the bottom of the hillslopes, and releases the remainder into the channel system where it is stored within the bed and banks of the debrisflow channel (e.g. Schürch et al., 2011; Bennett et al., 2012). The channel reservoir sediment balance is computed at the hourly resolution:

$$
\frac{d S_{c}}{d t}=\left(1-d_{h}\right) \cdot E_{h}(t)-O(t)
$$

where $S_{c}$ is the sediment volume stored in the channel system in $\mathrm{mm}, d_{h}$ is the hillslope redeposition fraction, $E_{h}$ is the hillslope erosion rate in $\mathrm{mm} \mathrm{h}^{-1}$, and $O(t)$ is the sediment discharge leaving the catchment in $\mathrm{mm} \mathrm{h}^{-1} . S_{c}$ represents the active storage in the channel system, i.e. sediment that can be eroded and refilled in addition to what is trapped permanently behind 30 check dams in the Illgraben channel, which were built to stabilize the channel and prevent vertical and lateral incision (Hürlimann et al., 2003; Bennett et al., 2013).

Sediment evacuation through the channel can occur by two mechanisms: bedload transport and debris flows. Bedload sediment transport occurs when there is surface runoff and no snow cover, because snow accumulations in the channel can hinder sediment transport. Therefore, bedload sediment transport is limited in winter, matching observations. The transport mechanisms are conditioned by a critical discharge $Q_{d f}$ and was calibrated to $2.4 \mathrm{~mm} \mathrm{~h}^{-1}$ (see section 3.3.3), corresponding to $3.2 \mathrm{~m}^{3} \mathrm{~s}^{-1} \cdot Q_{d f}$ partitions fluvial bedload transport and debris flows as follows:

$$
O_{\text {pot }}(t)=\left\{\begin{array}{cccc}
s_{\max } \cdot Q_{s}(t) \cdot A, & \text { if } & Q_{s}(t) \geq Q_{d f} \\
a \cdot Q_{s}(t)^{b} \cdot A, & \text { if } & Q_{s}(t)<Q_{d f}
\end{array}\right.
$$

where $s_{\max }$ is the dimensionless maximum volumetric sediment concentration, $O_{\text {pot }}$ is the transport-limited sediment output in $\mathrm{mm} \mathrm{h}^{-1}$, i.e. if sufficient sediments are stored in the channel, $A$ is the contributing drainage area, and $a$ and $b$ are parameters of the fluvial bedload transport rating curve.

Rating curves are widely-used to estimate sediment transport (Morris et al., 2008). Calibration of the parameters can be avoided by fixing the shape parameter $b=1.5$ which is a common value for bedload transport formulae of this form (e.g Meyer-Peter \& Müller, 1948; Fernandez Luque \& Van Beek, 1976; Wilson, 1966). The scale parameter $a$ can then be computed with the condition $a \cdot Q_{d f}^{b}=s_{\text {min }} \cdot Q_{d f}$, which ensures that the sediment concentration for bedload transport is lower than for debris flows. The parameter $s_{\text {min }}$ was set to 0.4 , which corresponds to a bulk density of $1640 \mathrm{~kg} \mathrm{~m}^{-3}$ and is at the lower end of debris flow observations in the Illgraben (McArdell et al., 2007).

The sediment discharge $O(t)$ in $\mathrm{mm} \mathrm{h}^{-1}$ is also dependent on the sediment available in the channel storage $\left(S_{c}\right.$ in $\left.\mathrm{mm}\right)$ during the modelling time step $\Delta t$ :

$$
O(t)= \begin{cases}O_{p o t}(t), & \text { if } S_{c}(t) \geq O_{p o t}(t) \cdot \Delta t \\ S_{c}(t), & \text { if } S_{c}(t)<O_{p o t}(t) \cdot \Delta t\end{cases}
$$

The volumetric sediment concentration in every sediment discharge event therefore ranges from 0 to a maximum of $s_{\max }$. Bennett et al. (2014) showed that in $39 \%$ of the cases

This article is protected by copyright. All rights reserved. 
when the debris-flow triggering discharge is exceeded in the Illgraben, debris-flow occurrence can be absent due to sediment not being available, highlighting the importance of accounting for sediment storage in the system. We refer to debris flows as events equaling or exceeding a sediment volume of $Q_{d f} \cdot s_{\min } \cdot A$ and a sediment concentration of $s_{\text {min }}$.

An example of five years of simulation with SedCas for the present climate is shown in Figure 3. The required climatic inputs are hourly precipitation, air temperature and incoming short-wave radiation. Snowmelt and rainfall produce runoff. Once the surface discharge threshold is exceeded $\left(Q_{s}>Q_{d f}\right)$ sediment transport events are generated. The volume of transported sediment is determined by $Q_{s}$ and $s_{\max }$ and by the availability of sediment in active channel storage $S_{c}$. $S_{c}$ evolves based on thermal landslide triggering with stochastic magnitudes, which occur mostly in early winter and spring (Berger et al., 2011b) when frost-cracking is most intense, and by the intermittent output of sediment by discharge events and debris flows. Simulated sediment transport events start in spring when there is little snow cover, rainfall can be high, and when there is usually ample sediment in storage.

\subsubsection{SedCas Calibration}

The degree-day model for snow accumulation and melt is re-calibrated at hourly resolution against snow records from Grimentz (Figure 1). Setting the temperature thresholds for accumulation and melt to 0.6 and $0.5^{\circ} \mathrm{C}$, respectively, and the melt rate factor to $0.08 \mathrm{~mm}{ }^{\circ} \mathrm{C}^{-1} \mathrm{~h}^{-1}$ resulted in the best fit with regard to the root mean square error of the simulated and observed snow water equivalent.

The parameters of the sediment production and transport model were calibrated by Bennett et al. (2014). The probability distributions for slope failures (i.e. both shallow landslides and rockslides or rockfall) were estimated in Bennett et al. (2012). The hillslope reservoir storage capacity $S_{h}^{*}$ in $\mathrm{mm}$ was estimated from observed deposition volumes by DEM differencing (Bennett et al., 2013).

Extending the hydrological model left us with nine parameters to be calibrated: three water storage capacities $\left(S_{w, 1}^{* v}, S_{w, 2}^{* v}, S_{w, 1}^{* n v}\right)$, three saturated mean residence times $\left(k_{1}^{v}, k_{2}^{v}, k_{1}^{n v}\right)$, the critical surface discharge for debris-flow triggering $\left(Q_{d f}\right)$, the maximum possible debris-flow sediment concentration $\left(s_{\max }\right)$ and the shape parameter of the landslide magnitude-frequency distribution $\left(\alpha_{l s}\right) . \alpha_{l s}$ controls the long-term hillslope erosion rate and is re-calibrated because it originally was determined for a period up to the year 2005. It is not certain, however, if the hillslope erosion rate remained unchanged in the following years. Additionally, including it in the re-calibration allows for testing the model sensitivity to this parameter.

There is no discharge measurement against which the hydrological module can be calibrated. Theoretically, it would be possible to measure discharge at the force plate, but the channel is often dry and water flow seldom covers the entire width of the force plate. Therefore, instead of calibrating the hydrological parameters and the debris-flow parameters separately, we perform a joint calibration of hydrological and debris-flow parameters using Monte Carlo simulations and posterior analysis. Here, we adapted the Generalized Likelihood Uncertainty Estimation (GLUE, Beven \& Freer, 2001) concepts to SedCas and the available observations. GLUE builds on the concept that multiple model parameter sets reproduce the field observations equally or within an acceptable range (Beven, 1993).

Given a model $(M)$ and a specific set $k$ of model parameters $\left(\phi_{k}\right)$, model estimators $\left(y_{k}\right)$ can be simulated:

$$
M\left(\phi_{k}\right)=y_{k}=\left(y_{k 1}, y_{k 2}, \ldots, y_{k n}\right)
$$

This article is protected by copyright. All rights reserved. 

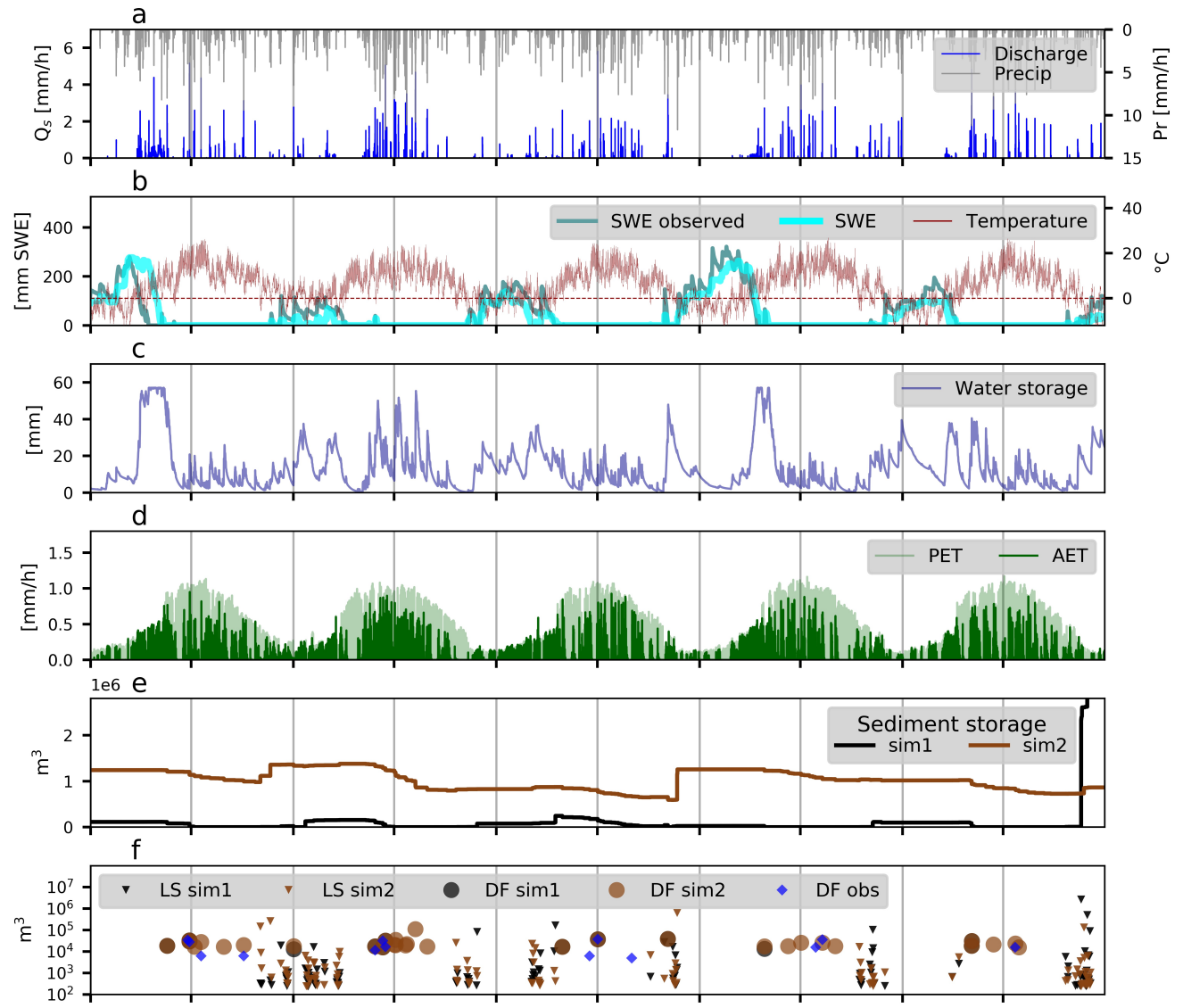

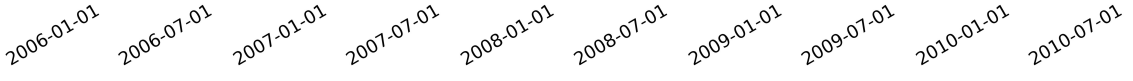

Figure 3. Example of SedCas inputs and outputs: (a) measured precipitation and simulated discharge; (b) measured temperature, and measured and simulated snow water equivalent (SWE); (c) simulated catchment-wide water storage; (d) simulated potential and actual evapotranspiration (PET, AET); (e) simulated channel sediment storage; and (f) simulated landslides (LS) and debris flows (DF) for a supply-limited (sim1) and a supply-unlimited (sim2) scenario, and observed debris flow-magnitudes (DF obs). The figure exemplifies that debris-flow events later in the debris-flow season only happen when sediment availability is sufficient.

This article is protected by copyright. All rights reserved. 
Applied to SedCas, $\phi_{k}$ is the vector with the nine parameters which require a calibration (Table 1). $y_{k}$ are the $n$ outputs of interest. By comparing them to field observations $y_{o}=\left(y_{o 1}, y_{o 2}, \ldots, y_{o n}\right)$, weighted relative residuals $\left(\pi_{k}\right)$ can be computed:

$$
\pi_{k}=\lambda \frac{y_{k}-y_{o}}{y_{o}}=\left(\pi_{k 1}, \pi_{k 2}, \ldots, \pi_{k n}\right)
$$

where $\lambda \epsilon[0,1]$ is the vector of weights which can be assigned to each observation $\left(y_{o 1}, y_{o 1}, \ldots, y_{o n}\right)$. This gives the opportunity to weigh observations according to their reliability or importance for the model purpose.

Because SedCas aims at reproducing first-order characteristics like debris-flow frequency and magnitudes, the primary objective is the minimization of residuals on simulated debris-flow statistics against the observations: average magnitude, standard deviation and the number of debris flows during the modelling period. Additionally, the Hydrological Atlas of Switzerland (2015) provides an estimate of mean annual actual evapotranspiration rates $\left(370 \mathrm{~mm} \mathrm{y}^{-1}\right)$, which we include in our objective function as a hydrological observation. A further constraint is that the hillslope erosion rate and sediment yield should be on average in equilibrium over the modelling period (i.e. the ratio of average sediment output to sediment production is equal to 1). This is justified by the fact that no significant sediment accumulation was observed in the catchment between 1963 and 2005 (Bennett et al., 2013). Therefore, $y_{o}$ is a vector of the five above-mentioned observations and the objective function is minimizing the modulus of Eq. $8(|\pi|)$. The three observations of debris-flow statistics were given a weight of 1 because they are direct observations. The ratio of long-term sediment yield to production was given a weight of 0.75 because it is not a direct observation. The mean annual evapotranspiration was given a weight of 0.5 because it is also not a direct observation and we see it as less important for producing debris flows.

10'000 SedCas parameter sets were sampled from a prior uniform distribution within chosen ranges using the Sobol quasi-random sequence, which has been shown to reduce the complexity of sampled parameter combinations and improve convergence (Sobol, 1976; Saltelli et al., 2008). This allows for a variance-based sensitivity analysis of the SedCas model. First-order Sobol indices explain which portion of the variance in the output can be attributed to the variance in each input. The total effect index additionally accounts for higher-order effects due to interactions of inputs (Saltelli et al., 2008). The highest first-order and total effect (Figure S4) stems from the debris-flow runoff threshold $\left(Q_{d f}\right)$, which is intuitive because it has a strong influence on the number of debris flows. First-order effects of the hydrological parameters seem negligible. However, the storage capacity of the non-vegetated HRU resevoir $\left(S_{w, 1}^{* n v}\right)$ contributes to the total effects because the reservoir capacity is relatively small and it controls the frequency of surface runoff events associated with sediment transport. $s_{\max }$ is also a sensitive parameter because it directly affects the magnitudes of supply-unlimited events and therefore also the sediment yield. In summary, $Q_{d f}$ and $S_{w, 1}^{* n v}$ are the parameters with the largest controls on the model outputs. Therefore, better constraints on them would significantly decrease the uncertainties in future research. SedCas is not very sensitive to the other model parameters.

During calibration we chose behavioural parameter sets, i.e. the parameter sets leading to model results within an acceptable range (Beven \& Freer, 2001). We consider parameter sets resulting in $\left|\pi_{k}\right| \leq 0.3$ as acceptable, which corresponds to an error of $15 \%$ per objective on average (i.e. if $\frac{y_{k}-y_{o}}{y_{o}}$ in Eq. 8 is a vector containing values of 0.15). Models with $\pi_{k}$ above the threshold are rejected (Figure S2). The debrisflow statistics are reproduced with biases of less than $23 \%$ among behavioural parameter sets and less than $4 \%$ for the best parameter set (Table S1). The ratio of sediment yield to sediment production and mean annual evapotranspiration can be underestimated by up to $50 \%$, but their biases are weighted in the objective function as described above. The parameter set where $|\pi|$ is smallest corresponds to the parameter set of max-

This article is protected by copyright. All rights reserved. 
Table 1. SedCas model parameters. Descriptions of original parameters can be found in Bennett et al. (2014). Some of the parameters were re-calibrated as described in Bennett et al. (2014) (x), others were added $\left(^{*}\right)$. The 9 parameters which are subject to the calibration scheme presented here are also marked $(\mathrm{xx})$ and correspond to the maximum likelihood parameters. Parentheses are used to separate parameters belonging to the vegetated and non-vegetated HRUs.

\begin{tabular}{|c|c|c|c|c|}
\hline Parameter & Description & Value & Unit & Calibration \\
\hline HRUs & Hydrological response units & 'vegetated', 'not-vegetated' & - & $*$ \\
\hline $\mathrm{A}_{H R U}$ & Relative HRU area from total area & $0.56,0.44$ & - & $*$ \\
\hline$S_{w}^{*}$ & Reservoir water storage capacities & $(72,27),(4)$ & $\mathrm{mm}$ & $\mathrm{xx}$ \\
\hline $\mathrm{k}$ & Mean residence time in saturated condition & $(94,235),(23)$ & $\mathrm{h}$ & $\mathrm{xx}$ \\
\hline$\alpha_{\text {snow }}$ & Albedo with snow & $0.4,0.65$ & - & $\mathrm{x}$ \\
\hline$\alpha_{\text {snow }}$ & Albedo without snow & $0.15,0.25$ & - & $\mathrm{x}$ \\
\hline$E$ & Mean catchment elevation & 1600 & m a.s.l. & \\
\hline$A$ & Catchment area & 4.83 & $\mathrm{~km}^{2}$ & \\
\hline$T_{s a}$ & Temperature threshold for snow accumulation & 0.6 & ${ }^{\circ} \mathrm{C}$ & $\mathrm{x}$ \\
\hline$T_{s m}$ & Temperature threshold for snow melt & 0.5 & ${ }^{\circ} \mathrm{C}$ & $\mathrm{x}$ \\
\hline$m$ & Snow melt rate factor & 0.08 & $\mathrm{~mm}^{\circ} \mathrm{C}^{-1} \mathrm{~h}^{-1}$ & $\mathrm{x}$ \\
\hline$\alpha_{E T}$ & Evapotranspiration efficiency factor & 20 & - & $\mathrm{x}$ \\
\hline $\mathrm{Q}_{d f}$ & Discharge threshold for debirs-flow initiation & 2.40 & $\mathrm{~mm} \mathrm{~h}^{-1}$ & $\mathrm{xx}$ \\
\hline $\mathrm{s}_{\max }$ & Max debris-flow sediment concentration & 0.57 & - & $\mathrm{xx}$ \\
\hline $\mathrm{s}_{\min }$ & Min debris-flow sediment concentration & 0.4 & - & $*$ \\
\hline $\mathrm{a}$ & Scale factor for bedload transport & 'auto' & - & * \\
\hline $\mathrm{b}$ & Exponent for bedload transport & 1.5 & - & * \\
\hline $\mathrm{d}_{h}$ & Hillslope redepostion rate & 0.12 & - & \\
\hline $\mathrm{DF}_{\min }$ & Min observed debris flow, total volume & 2000 & $\mathrm{~m}^{3}$ & \\
\hline$\rho_{b}$ & Density of bedrock & 2600 & $\mathrm{~kg} \mathrm{~m}^{-3}$ & * \\
\hline$\rho_{d r y}$ & Bulk density of stored sediments & 2000 & $\mathrm{~kg} \mathrm{~m}^{-3}$ & * \\
\hline$\rho_{\text {bulk }}$ & Bulk density of observed debris flows & 2000 & $\mathrm{~kg} \mathrm{~m}^{-3}$ & $*$ \\
\hline $\mathrm{S}_{\text {hcap }}$ & Hillslope sediment storage capacity & 750000 & $\mathrm{~m}^{3}$ & \\
\hline $\mathrm{ls}_{\min }$ & Min possible landslide & 233 & $\mathrm{~m}^{3}$ & \\
\hline $\mathrm{ls}_{\max }$ & Max possible landslide & $3 \cdot 10^{6}$ & $\mathrm{~m}^{3}$ & \\
\hline$\alpha_{l s}$ & shape parameter for landslide distribution & 1.69 & - & $\mathrm{xx}$ \\
\hline$s_{l s}$ & Snow SWE threshold for landslide triggering & 20 & $\mathrm{~mm}$ & $\mathrm{x}$ \\
\hline
\end{tabular}

imal likelihood. The posterior distributions do not show significantly higher frequencies at the boundaries of their prior distributions (Figure S3), indicating that the parameter ranges were chosen wide enough.

In order to reproduce the climatic conditions important for landslides when using AWE-GEN rather than observational forcing, we had to slightly adjust the two SedCas parameters controlling the onset of frost-weathering. Thus, we adjusted the temperature threshold for freezing conditions from 0 to $-0.4^{\circ} \mathrm{C}$ and the no-snow threshold from 20 to $15 \mathrm{~mm}$ because AWE-GEN appears to underestimate low winter temperatures. We made these adaptations so that the number of freezing days, no-snow days and landslides are within the internal climate variability computed with AWE-GEN forcing.

\subsection{Advanced Weather Generator (AWE-GEN)}

Hourly time series of climatic variables representative of present and future climates are simulated using the AWE-GEN stochastic weather generator (Fatichi et al., 2011), which is parameterized with the data of the observed climate for the historical period (1981-2010), and by combining the observed climate and factors of change of climate statistics derived from the CH2018 climate scenarios for the future periods (Figure 2). The stochastic downscaling approach follows the design of Fatichi et al. (2016) where additional details can be found.

This article is protected by copyright. All rights reserved. 

Figure 2). 2018, Table 4.1). leg et al., 2019; Peleg, Sinclair, et al., 2020).

AWE-GEN is a simulator of hourly time series of correlated weather variables (e.g. precipitation, cloud cover, air temperature, shortwave radiation) based on the hypothesis of stationarity in statistical properties of climate variables. The model parameters are estimated from observations, using a range of statistics estimated for different aggregation scales (from hourly to annual). An ensemble of climate variables was simulated for four periods of interest: the historical period (1981-2010) that is used as a reference scenario, and three future scenarios that are centered on the years 2035, 2060 and 2085. For each ensemble, $N=50$ realizations were simulated, each with $L=30$ years (members), to represent the internal climate variability (Kim et al., 2016a) (see

We compute FC (Factors of Change) from the CH2018 scenarios using the most critical emission scenario RCP8.5, i.e. the scenarios characterized by the highest emission of greenhouse gases leading to an added radiative forcing of $8.5 \mathrm{~W} \mathrm{~m}^{-2}$ at the end of the $21^{\text {st }}$ Century (Riahi et al., 2011; Moss et al., 2010). The scenarios for different model chains are used to estimate FC as ratios (precipitation) or differences (temperature) between the reference and the future periods of climate statistics at various temporal aggregation scales (from daily to annual). We only considered the 10 model chains of the highest spatial resolution of $0.11^{\circ}$ that were used in previous studies to simulate precipitation in Alpine regions (e.g. Giorgi et al., 2016; Peleg et al., 2019), although up to 31 model chains are available from CH2018 at coarser spatial resolution (see CH2018,

We use the CH2018 gridded scenario product, and for each model chain we extract the data from four grid cells covering the Illgraben and compute its mean. The FC from all model chains are weighted using a Bayesian methodology to obtain probability distributions of the FCs and to subsequently recompute different model parameter sets for AWE-GEN, each one representing a possible future climate trajectory. Since CH2018 has a daily temporal resolution, we apply FC to AWE-GEN parameters of daily or lower temporal resolution only and assume that the sub-daily parameters do not change (except for the mean). In the simulations, we generate $n p s=30$ parameter sets representing different climate trajectories, plus 1 parameter set corresponding to the median FC, and therefore to the median future climate for a specific period.

Finally, we evaluate the contributions of climate model and stochastic uncertainty by comparing them with total uncertainty originating from $(30+1) \cdot 50=1550$ plausible time series of hourly precipitation and air temperature for each future climate period. To this end we plot the $10-90^{t h}$ percentiles on the changes from reference to 2035 , 2060 and 2085 for each month. We first compute the total uncertainty, defined as the $10-90^{t h}$ percentiles range of the entire 1550 members within an ensemble. Second, we estimate the uncertainty emerging from the climate model by computing the 10-90 ${ }^{\text {th }}$ percentile of the median of 30 years for each of the 31 realizations (nps + median FC) and then we compute the $10-90^{\text {th }}$ percentile of the obtained values. Last, the internal climate variability (stochastic uncertainty) was computed, defined as the $10-90^{\text {th }}$ percentile range of all 50 members within the median FC. This procedure follows the methodology proposed by Fatichi et al. (2016). We do this for the input variables precipitation and air temperature as well as for SedCas simulated variables surface runoff and sediment yield. The overall number of sampled parameter sets (nps) and number of ensembles $(N)$ were chosen pragmatically so that robust confidence bounds were obtained within a reasonable computation time (similar to Fatichi et al., 2013, 2016; Pe- 


\section{Results}

\subsection{Historical Sediment Yield Modelled with SedCas}

SedCas was calibrated against observations of first-order debris-flow characteristics (magnitude mean and standard deviation, and number of debris flows) which are therefore simulated within acceptable ranges (Figure S2, Table S1). Seasonal variability in debris-flow yield (Figure 4) is another first-order characteristic which, however, was not considered in the calibration process and can therefore be used as supporting evidence of the model performance. Simulated and observed seasonal patterns fit well and the range of simulated debris-flow yield given by the behavioural parameter sets (i.e. the parameter sets leading to model results within an acceptable range) contains the observation for each month. Only during October does the model uncertainty range not fit the observations of debris flow yields, and here the model underestimates. The simulations show debris-flow activity outside of the observed debris-flow season in winter and especially in April. This is likely primarily due to peak snowmelt, which occurs quite early in the season. The model only considers temperature at the mean basin altitude in determining the onset of snow melt and thus debris flow triggering, whereas temperatures can still be below melting point in the upper parts of the catchment from which debris flows are commonly initiated (Berger et al., 2011b).

For climate change impact assessment we use only the parameter set of maximum likelihood, i.e. least total residual. Even though mean monthly debris-flow yields can deviate by up to $\pm 60 \%$ depending on the chosen parameter set, the seasonal regime is similar. However, because the behavioural parameter sets have different values of $\alpha_{l s}$ and therefore different mean hillslope erosion rates, some of the spread in the model outputs reflects the consequence of the differences in sediment storage.

\subsection{Climate Change Impacts on the Hydrological Regime}

Changes in the hydrological regime have a significant impact on sediment output by bedload transport and debris flows. In SedCas, debris flows are triggered if surface discharge exceeds a threshold and if channel sediment storage is sufficiently filled. Therefore, we analyze changes in seasonal and extreme precipitation and how it is reflected in seasonal and extreme discharge.

For all three future scenarios 2035, 2060 and 2085 a trend towards wetter winters, springs and autumns, and drier summers is identifiable from the CH2018 climate change projections with stronger magnitudes of this trend towards the end of the century (Figure 5a). However, the no-change scenario is still within the uncertainties of a possible future climate, except for the summer decreases in precipitation in 2060 and 2085. Total uncertainties in precipitation projections mostly stem from internal climate variability and not from climate model uncertainty, which reflects the high variability of precipitation in the study area even in a stationary climate (Figure 5a). Although precipitation is expected to increase in 8 months of the year, only relatively minor increases are expected in total annual precipitation (median FC of 1.05, 1.09 and 1.15 for 2035, 2060 and 2085, respectively).

Climate change signals in precipitation frequencies simulated with AWE-GEN are subject to uncertainties stemming mostly from internal variability (Figure S5a,b). However, changes can still be detected in the median and upper and lower boundaries. Precipitation intensities are expected to increase slightly in all seasons and across temporal aggregation scales, with the exception of winter precipitation intensities which remain similar. This figure also confirms that the AWE-GEN model simulates extreme precipitation accurately for the reference period at an hourly and daily basis.

This article is protected by copyright. All rights reserved. 

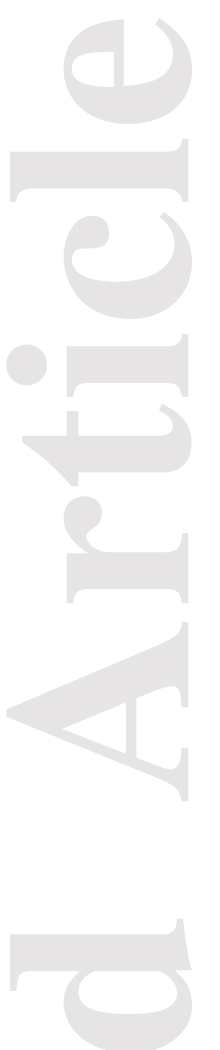

595

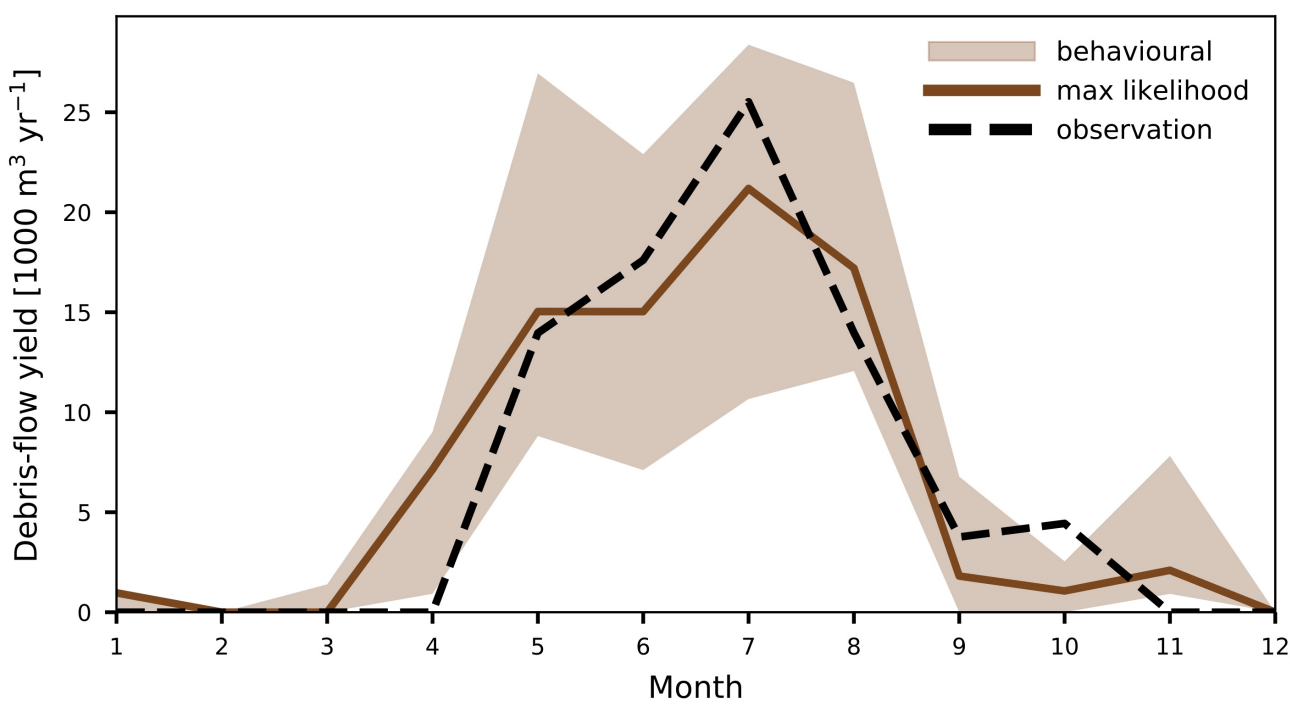

Figure 4. Mean monthly debris-flow yield modelled with SedCas, the observed climate and the behavioural parameter sets $(n=102)$, i.e. the parameter sets leading to model results withing an acceptable range, for the calibration period 2000-2017. The parameter set of maximum likelihood (solid brown line) is used for climate change impact assessment. The range of all behavioural parameter sets is shaded. Modelling results match the seasonal pattern well compared to the debris-flow observations at the force plate (dotted black line). Debris-flow volumes were computed using the median bulk density from the observations $\left(1800 \mathrm{~kg} / \mathrm{m}^{3}\right)$.

In addition we also analyze the fraction of no precipitation (Figure S5c), which has implications on antecedent wetness conditions of the watershed and therefore on the number of possible surface-runoff and sediment-transport events. The fraction of no precipitation at the daily scale is projected to increase in the summer months for all future periods, up to $\sim+10 \%$ towards the end of the century. In the spring months changes are not as significant, but fewer dry days can be expected $(\sim-3 \%)$. No clear signal is discernible in the other seasons.

Air temperatures simulated with AWE-GEN for the study area on the other hand shows a strong and consistent climate change signal, well beyond the internal climate variability (Figure 5b). For all future periods the increases are smaller in winter (ca. $0.5,2$ and $3^{\circ} \mathrm{C}$ ) and higher in summer (ca. 2,4 and $6^{\circ} \mathrm{C}$ ) on the average. In contrast to precipitation, large portions of uncertainty can be attributed to the uncertainty in the climate models, especially in summer. These changes have a strong influence on snow-related processes and the water balance of the study area.

Impacts of changes in precipitation and temperature are reflected in changes in mean monthly surface runoff contributing to sediment transport $\left(Q_{s}\right)$ simulated with SedCas (Figure 5c). For the 2035 scenario FCs of $Q_{s}$ still lie within the no-change scenario. Later in the century winter $Q_{s}$ significantly increases up to a factor of 2.5 due to the increased liquid precipitation. Spring $Q_{s}$ decreases due to a shift in peak snow melt (Figure S6), May is an exception because this month is mostly snow-free also in the reference period, and precipitation amounts are increasing. Summer $Q_{s}$ decreases by $\sim-40 \%$ and autumn $Q_{s}$ increases by $\sim+50 \%$ due to changes in precipitation. Here, most of the uncertainties can be explained with internal climate variability. However,

This article is protected by copyright. All rights reserved. 
a decreasing trend in mean monthly $Q_{s}$ does not imply a drop in the frequency of debrisflow triggering hourly discharge, because these depend on the magnitude of individual discharge events.

Changes in surface discharge above the debris-flow triggering threshold $Q_{d f}$ will directly be reflected in changes in the $Q_{s}$ magnitudes with the potential to trigger debris flows (Figure 6). The frequency with which discharge exceeds the debris-flow triggering threshold $\left(Q_{s} \geq Q_{d f}\right)$ is expected to increase by $\sim+30 \%$ in the short- and midterm scenario and by $\sim+50 \%$ in the long-term scenario. Significant increases are expected in all seasons, except for the summer months where the median stays similar through all periods $\left(\sim 5 \mathrm{~h} \mathrm{yr}^{-1}\right)$. In spring and autumn, gradual increases of the medians from 0.8 to 1.8 and 1.6 to $3.4 \mathrm{~h} \mathrm{yr}^{-1}$ by the end of the century, respectively, indicate that more debris flows are likely in shoulder seasons.

\subsection{Hillslope Landslide Triggering Under Climate Change}

The effect of climate change on sediment production by frost-weathering and subsequent landsliding is critical for the sediment dynamics because it drives the accumulation of sediment stored in the channel system. In fact, the thermal conditioning for hillslope landsliding (snow cover $s<s_{l s}$ and mean daily temperature $T<0^{\circ} \mathrm{C}$ ) makes the landslide triggering conditions and timing very sensitive to both temperature and precipitation.

Changes in the frequency of landslide triggering conditions are evident when looking at the median number of freezing days $\left(T<0^{\circ} \mathrm{C}\right)$ which show a significant drop from 90 days per year in the reference period to 76 in the 2035 scenario, 60 in the 2060 scenario and finally to 43 in the 2085 scenario (green boxplots for $1600 \mathrm{~m}$ a.s.l. in Figure 7). Similarly, the simulated days with no substantial snow cover $\left(s<s_{l s}\right)$ show a significant rise from 269 days per year in the reference period to 329 in the 2085 scenario. Both conditions have to be met simultaneously for landslide triggering. This results in a median of 30 landslides per year in the reference period, 27 in the 2035 and 2060 scenarios, and 24 in the 2085 scenario.

SedCas was calibrated for the mean elevation of $1600 \mathrm{~m}$ a.s.l. although the catchment ranges in elevation from 886 to $2645 \mathrm{~m}$ a.s.l. At different altitudes the number of days with coincidental freezing temperatures and no substantial snow cover can be different and therefore show a different change in the number of landslides. To explore this effect, snow cover was simulated in SedCas at elevation scenarios of 2000 and 2500 $\mathrm{m}$ a.s.l. by extrapolating the temperature input with lapse rates. In the study area, $20 \%(30 \%)$ and $2 \%(0 \%)$ of the total catchment area (of the active hillslope area) are above these elevations. The evolution in the number of landslides as a function of elevation show different behaviour, despite the fact that freezing days and no-snow days decrease and increase linearly at all elevations (Figure 7). In the reference period most landslides occur at $1600 \mathrm{~m}$ (30 per year) and significantly less at $2000 \mathrm{~m}$ (25) and 2500 (22). For the short-term projection this order is conserved with a drop of $\sim-3$ landslides per year at each elevation. In the long-term a significant decrease in the number of landslides per year is expected at $1600 \mathrm{~m}(\sim-6)$, a slight increase at $2000(\sim+2)$ and a significant increase at $2500 \mathrm{~m}(\sim+6)$. These changes result solely from the compensating roles of reduced freezing days and rising snow-free days acting on the hillslopes.

\subsection{Channel Sediment Output Under Climate Change}

Sediment output under climate change was investigated based on the number of debris flows per year, mean debris-flow magnitude and mean annual sediment yield (Figure 8). Comparing the simulations resulting from the AWE-GEN-SedCas model chain to observations and calibration results, the number of debris flows and the sediment

This article is protected by copyright. All rights reserved. 

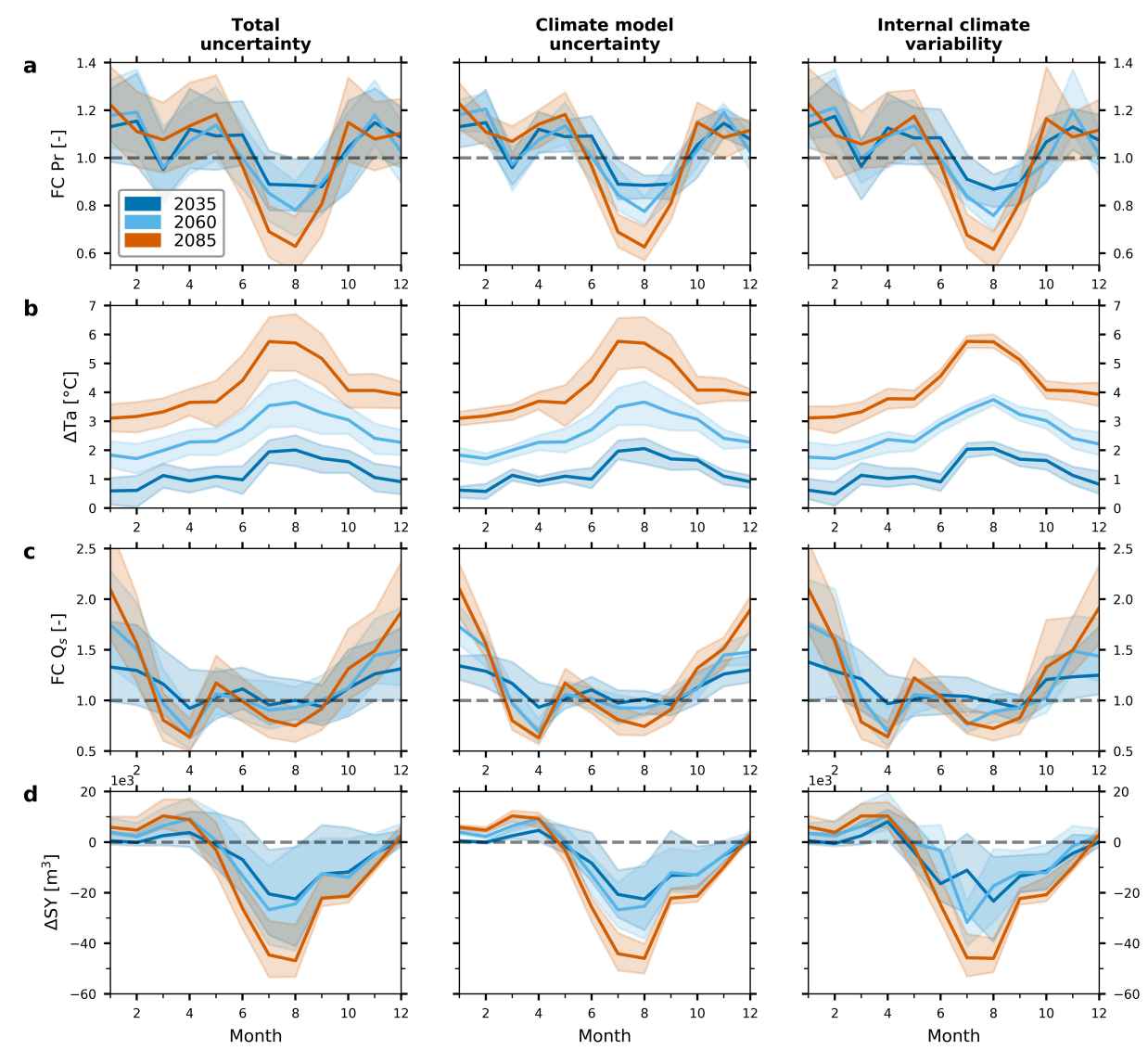

Figure 5. Changes of key climate variables and sediment yield at the study site for the three future periods centered around 2035 (blue), 2060 (green) and 2085 (red). The solid lines represent the medians and the shaded areas the $10-90^{\text {th }}$ percentiles. The horizontal dashed lines stand for the value of no change. The left column shows total uncertainties, the central column shows climate model uncertainties and the right column shows internal climate variability. (a) Factor of change in mean monthly precipitation (FC Pr) computed with AWE-GEN. (b) Change in mean monthly air temperature $(\Delta \mathrm{Ta})$ computed with AWE-GEN. (c) Factor of change in mean monthly surface runoff (FC $\left.\mathrm{Q}_{s}\right)$ computed with SedCas. (d) Change in mean monthly sediment yield ( $\Delta \mathrm{SY})$ computed with SedCas. 


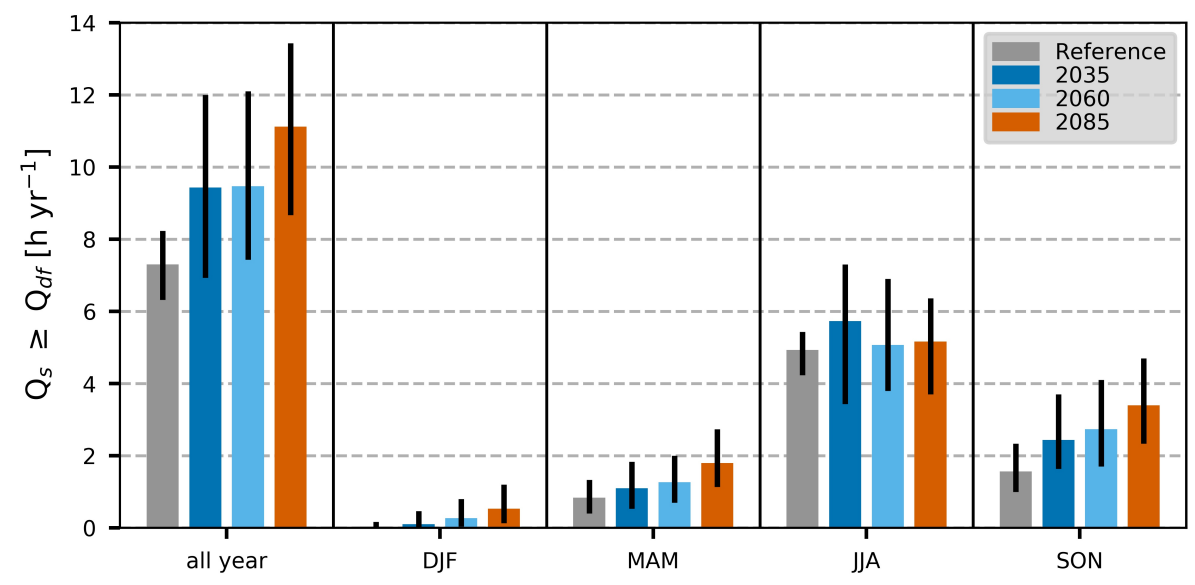

Figure 6. Current and future cumulative hours per year of surface runoff $\left(Q_{s}\right)$ exceeding the debris-flow triggering threshold $\left(Q_{d f}\right)$ for all year, winter (DJF), spring (MAM), summer (JJA) and autumn (SON). Error bars refer to the $10^{\text {th }}$ and $90^{\text {th }}$ percentiles. Discharge is computed with SedCas forced with the climate from AWE-GEN.

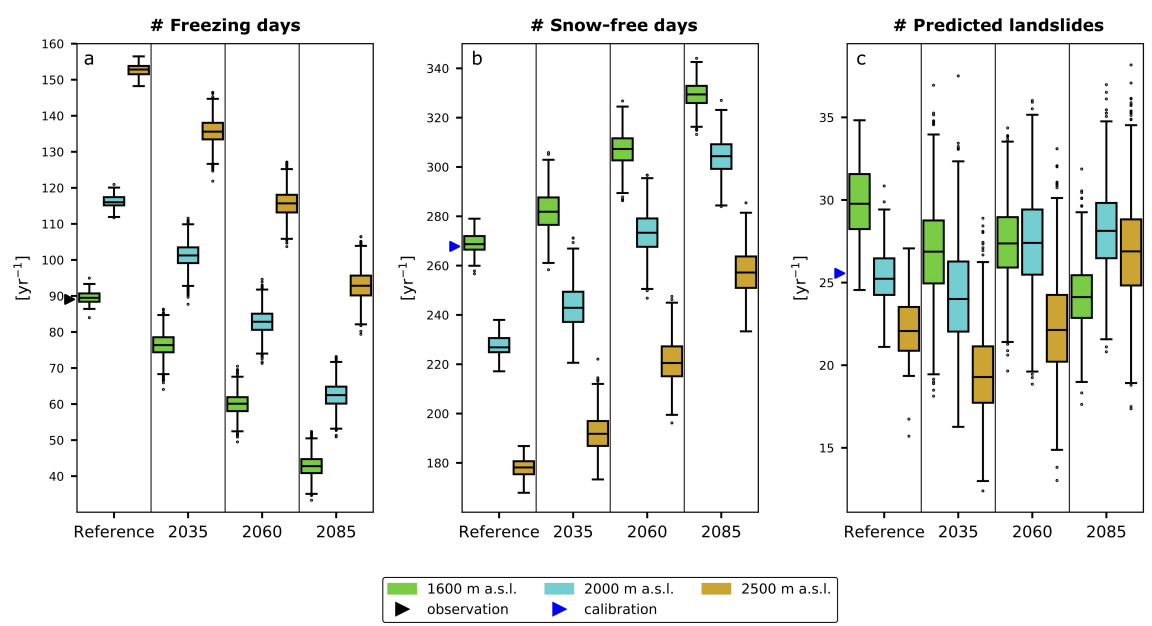

Figure 7. Boxplots of hillslope landslide triggering conditions for present and future climate. (a) Number of days with mean daily temperature $\bar{T}<0^{\circ} \mathrm{C}$ per year. (b) Number of days with little snow cover per year $\left(s<s_{l s}\right)$. (c) Number of days when both conditions are met and hillslope landslides are generated in SedCas. Direct observations are only available for the temperature. Snow-free days and landslides are compared to results of the calibrated model forced with observed climate. Boxplots are shown for three mean catchment elevation scenarios: 1600 (the actual mean), 2000 and $2500 \mathrm{~m}$ a.s.l. and for all AWE-GEN parameter sets and therefore the Reference consists of 50 (1 parameter set with 50 simulations) and the future scenarios of 1550 $(30+1$ parameter sets with 50 simulations each) data points.

This article is protected by copyright. All rights reserved. 
yield are well reproduced, i.e. the discrepancy lies within the uncertainties that are due to internal climate variability. Mean debris-flow magnitudes are overestimated by $20 \%$ or more (Figure $8 \mathrm{~b}$ ). Since the number of debris flows is well calibrated, the cause for this bias is likely related to the Poisson process in the AWE-GEN precipitation simulator, which produces more temporally correlated rainfall fields. However, the magnitudes simulated with AWE-GEN do not differ significantly among elevations, nor climate periods. These comparisons of simulated sediment statistics under the reference climate with observations (Figure 8) together with the comparisons of the landslide triggering conditions (Figure 7) gives credibility to the joint AWE-GEN and SedCas model chain for climate change impact assessment.

The climate change impact assessment on the debris-flow triggering discharge showed a tendency to a future increase in the number of debris flows (Figure 6). By contrast, when sediment supply is limited by frost-weathering, the median number of debris flows is expected to continuously decrease from a median of 3.2 per year in the reference period to 2.5 in the long-term projection at the catchment mean elevation (Figure 8). For the short- and the mid-term future, however, predictions largely fall within modelled uncertainties. Note that the range of uncertainties is larger for the 2035 and 2060 periods than for the 2085 period, which is probably a result of further temperature rise to levels where there are fewer fluctuations around $0^{\circ} \mathrm{C}$. This will result in less variability in both freezing days and snow cover, and therefore in landslides and snowmelt in the far future. Another reason could be less stochasticity in intense summer precipitation because the fraction of no precipitation increases. Debris-flow magnitudes show a slightly increasing trend but should not be overinterpreted due to the overestimation in the related magnitudes in the reference period and the wide range of uncertainties. Impacts on median total sediment yield at mean catchment elevation show a drop by $-23 \%$ both for the near- and mid-term projections and $-48 \%$ for the long-term projection (green boxes in Figure 8).

The predictions for the number of debris flows and total sediment yield differ depending on the elevation of the sediment source area considered (Figure 8). When considering the median values, a drop of $-23 \%$ is expected at $1600 \mathrm{~m}$ a.s.l., while only a small increase of $+9 \%$ and a more significant increase of $+21 \%$ is predicted for elevations at 2000 and $2500 \mathrm{~m}$ a.s.l., respectively, by the end of the century. The same pattern is apparent in the predictions of total sediment yield.

Changes in the monthly sediment yield from the reference to the future periods agree with the seasonal shift in precipitation and runoff (Figure 5d). We expect a considerable increase of sediment output during the winter months due to more liquid precipitation and sediment-laden snowmelt floods, and a considerable decrease in the summer months. Climate model uncertainty and internal climate variability contribute practically equally to the total uncertainty. This is different to the FC for precipitation and surface runoff where internal climate variability is dominant (Figures 5a,c). The decreases in sediment yield for the summer and autumn seasons suggest that the increase in precipitation intermittency and the decrease in sediment production outweigh the increase in high-intensity precipitation frequencies (Figures 7 and S5).

This becomes clearer when the supply-limited sediment yield, i.e. when frost-weathering limits the sediment supply to the channel by landsliding, is compared with the transportlimited sediment yield, i.e. when sediment storage is hypothetically abundant (Figure 9). At the default mean catchment elevation of $1600 \mathrm{~m}$, although the number of runoff events exceeding the debris-flow triggering threshold is predicted to increase in all months, sediment yield decreases due to sediment supply limitations. The months of June to October show particularly high decreases in sediment yield because the sediment supplied to the channel by landslides in autumn and spring is exhausted early in the year. When higher hypothetical mean catchment elevations are considered, the increase in debris flows and sediment yield can be attributed to a longer season during which sed-

This article is protected by copyright. All rights reserved. 

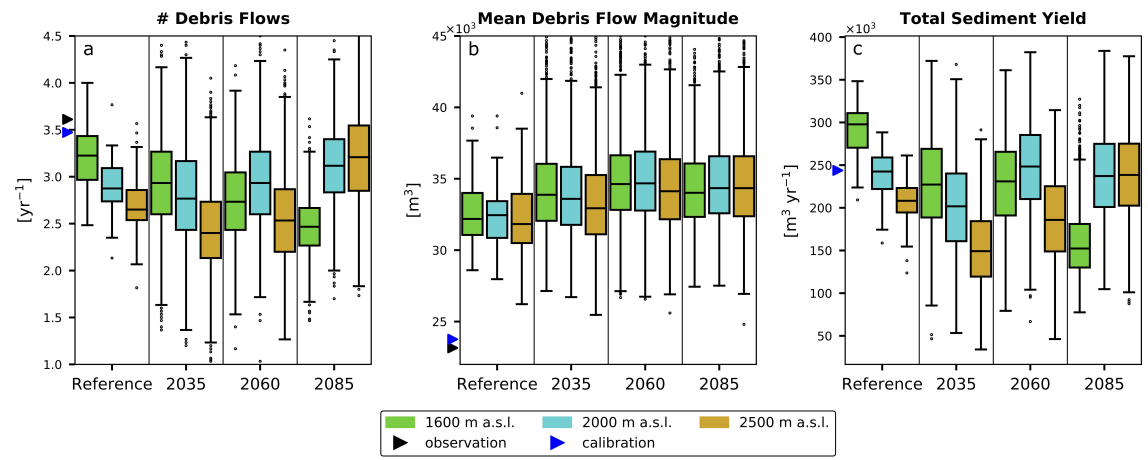

Figure 8. Boxplots of key sediment flux variables: (a) number of debris flows leaving the catchment and their (b) mean magnitude in $\mathrm{m}^{3}$ of solid material; (c) total sediment yield (debris flows plus bedload transport) in $\mathrm{m}^{3}$ of solid material. Observations (debris flows measured at the force plate) and calibration results (calibrated SedCas model forced with observed climate) refer only to the $1600 \mathrm{~m}$ a.s.l. scenario in the calibration period. Boxplots are shown for three mean catchment elevation scenarios: 1600 (the actual mean), 2000 and $2500 \mathrm{~m}$ a.s.l. and for all AWE-GEN parameter sets and therefore the Reference consists of 50 (1 parameter set with 50 stochastic simulations) and the future scenarios of $1550(30+1$ parameter sets with 50 simulations each) data points.

Table 2. Changes in supply-limited and supply-unlimited median sediment yields for the reference and three future periods, and for simulations with three different catchment mean elevations (in $\mathrm{m}$ a.s.l). The numbers in brackets are absolute sediments yields in units of $1000 \mathrm{~m}^{3} \mathrm{y}^{-1}$.

\begin{tabular}{cccccc}
\hline & Elevation & Reference & 2035 & 2060 & 2085 \\
\hline \multirow{3}{*}{ Supply-limited } & 1600 & $100 \%(281)$ & $-23 \%(217)$ & $-22 \%(219)$ & $-48 \%(147)$ \\
& 2000 & $100 \%(232)$ & $-19 \%(189)$ & $+2 \%(237)$ & $-3 \%(225)$ \\
& 2500 & $100 \%(203)$ & $-30 \%(143)$ & $-13 \%(176)$ & $+11 \%(226)$ \\
\multirow{5}{*}{ Transport-limited } & 1600 & $100 \%(330)$ & $+23 \%(408)$ & $+31 \%(433)$ & $+48 \%(489)$ \\
& 2000 & $100 \%(326)$ & $+15 \%(376)$ & $+18 \%(384)$ & $+34 \%(437)$ \\
& 2500 & $100 \%(260)$ & $+18 \%(308)$ & $+24 \%(324)$ & $+48 \%(384)$ \\
\hline
\end{tabular}

iment transport is possible (Figure S7). The numbers are reported in Table 2 and show that at $1600 \mathrm{~m}$ a.s.l. a potential increase in sediment yield by $+24,+31$ and $+48 \%$ for 2035, 2060 and 2085, driven by an increase in debris-flow triggering runoff events, is limited by sediment supply, resulting in a decrease in sediment yield of $-23,-22$ and $48 \%$ instead.

\section{Discussion}

\subsection{Climate Change Impacts on the Illgraben Sediment Cascade}

Results suggest that a highly uncertain change in precipitation combines with a less uncertain and much stronger change (rise) in air temperature to generate a considerable response in sediment yield by the end of the $21^{\text {st }}$ century. We have shown that despite hydrological changes causing substantial increases in runoff events with the potential to trigger debris flows (Figure 6), a climate-induced reduction in sediment pro-

This article is protected by copyright. All rights reserved. 

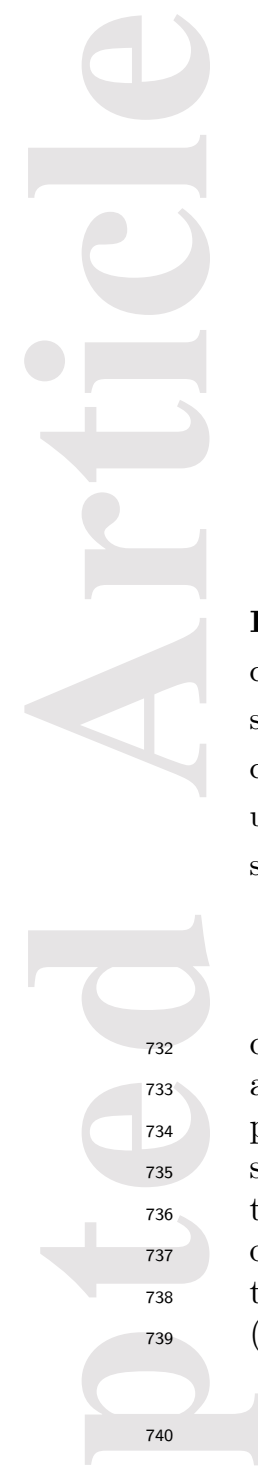

741
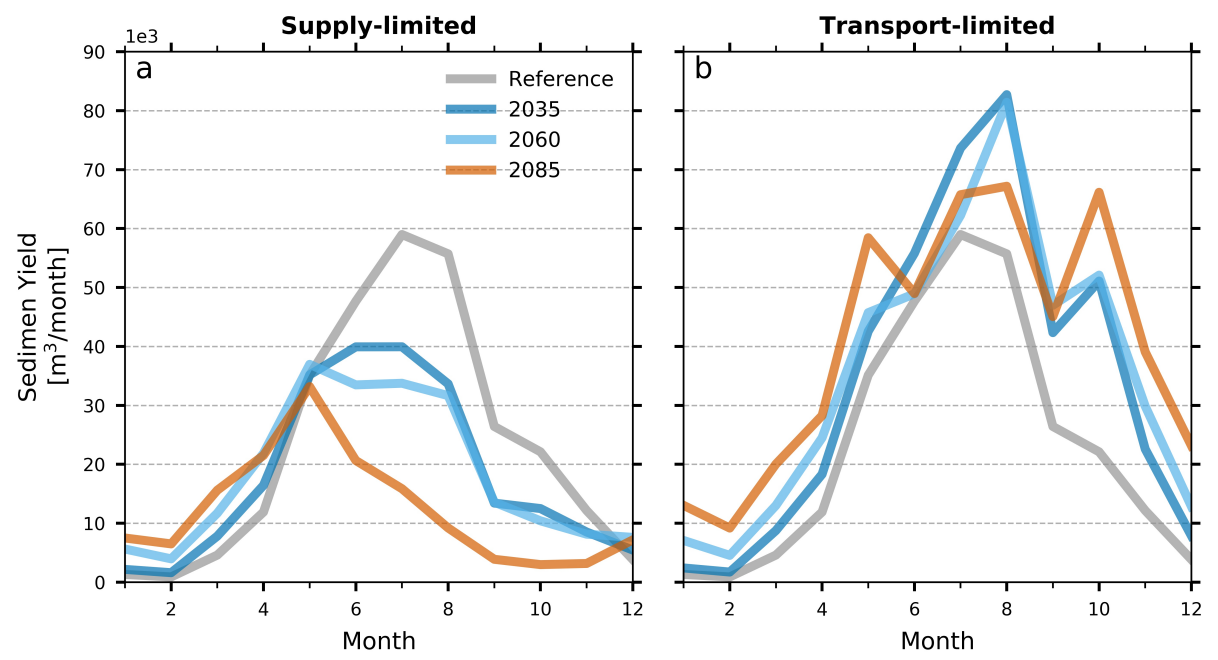

Figure 9. Mean monthly sediment yield at the Illgraben mean basin elevation (1600 m a.s.l.) computed with SedCas for the reference and three future periods. (a) Sediment yield when landslide sediment supply is limited by frost-weathering. (b) Sediment yield in transport-limited conditions, i.e. when sediment supply is hypothetically unlimited. The figure shows median simulation results. Sediment yields for all elevations and associated uncertainties are shown in the supplementary information (Figure S7).

duction (Figure 6) limits debris-flow generation and sediment transport. Thus $-48 \%$ and $-23 \%$ decreases in median sediment yield and debris-flow events, respectively, are predicted (Figure 8, Table 2). The short- and mid-term projections (2035 and 2060) show the same trend but remain within the natural variability, making inferences for these time periods very uncertain (Figure 8). Our results demonstrate the importance of understanding interactions of sediment supply and hydrological conditions and how they may change in a future climate. This is summarized in a simple conceptual scheme (Figure 10).

\subsection{Sediment Cascade Sensitivity to Elevation}

To address one consequence of the lumped nature of the model, we explored the influence of the catchment elevation by varying the mean catchment elevation from 1600 to 2000 and $2500 \mathrm{~m}$ a.s.l., and analyzed future changes in sediment yield and debrisflow activity. This is of relevance both for the study area with a large altitudinal range (886 - $2645 \mathrm{~m}$ a.s.l.) and for other Alpine catchments where sediment production areas may shift in a changing climate. Although sediment yield is predicted to decrease in the long term at lower elevations $(<2000 \mathrm{~m})$, increases are predicted at higher elevations (Figure 9) due to a sensitive balance of reduction in freezing days (dominant $<2000 \mathrm{~m}$ ) and increase in snow-free days (dominant $\geq 2000 \mathrm{~m}$ ) controlling sediment production by frost-weathering (Figures 8 and 11). These results support first observations on shifts in source areas to higher altitudes made in the Massif des Ecrins (French Alps) in the past decades (Jomelli et al., 2004). At lower altitudes, the number of freezing days and the debris-flow activity dropped during the same period. However, these results may not apply to other hillslope sediment production mechanisms, e.g. landslide triggering by rainfall. Our work highlights the importance of knowing where both the sediment production and debris-flow triggering areas are situated in environments where sediment supply is driven by temperature-related processes.

This article is protected by copyright. All rights reserved. 


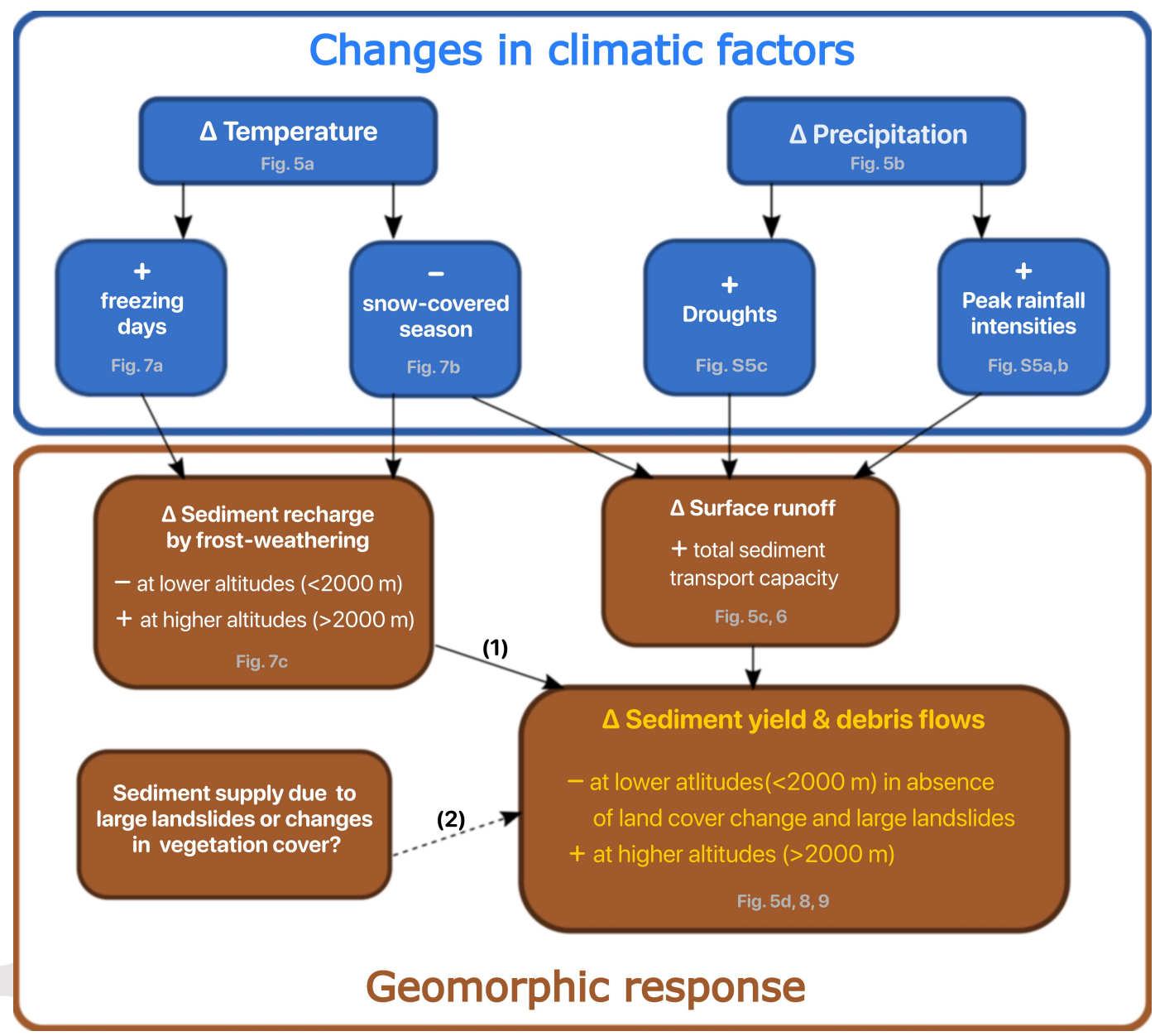

Figure 10. Simplified conceptual scheme of how future expected changes in climatic factors will translate to a geomorphic response in sediment recharge and transfer processes in the study area. The main sediment recharge mechanism considered in the SedCas model is by frost-weathering (1). Other sediment sources are possible but unsure (2) and are not directly implemented in SedCas.

This article is protected by copyright. All rights reserved. 


\subsection{Partitioning of Uncertainties}

We partitioned the total predictive uncertainty in precipitation, temperature, discharge and sediment yield to the parts stemming from uncertainties in climate models and internal climate variability (stochastic uncertainty). We have shown that stochastic uncertainty is responsible for most of the total uncertainty in changes in precipitation and that uncertainties in temperature are more balanced between stochastic and climate model uncertainty (Figure 5a,b). This is in agreement with other studies (e.g. Fatichi et al., 2013, 2016; Peleg et al., 2019). For sediment yield, the partitioning of uncertainties is also more balanced as a consequence of the strongly temperature-dependent landslide-triggering mechanism controlling the sediment availability (Figure 5d). This has the surprising effect of reducing uncertainty with the more extreme temperatures predicted for the future, because in Alpine basins where sediment production is influenced by freezing conditions, extreme climate warming shifts a progressively higher proportion of basins into regimes more distant from the $0^{\circ} \mathrm{C}$ line. Another interesting result is that the variance in predicted precipitation, discharge, landslides, debris flows and sediment yield are smaller for the long-term, or at least not greater, than for the short-term predictions. Likely, this is the result of using a severe emission scenario where the climate signal on the long-term becomes so strong that changes in threshold dependent processes (e.g. snow accumulation) become more evident. Another reason is that as summers become more dry, the stochasticity in summer rainfall decreases.

We focused on a severe emission scenario RCP 8.5 because it covers the largest range of climatic changes, making it the most suitable emission scenario to explore possible risks related to climatic extremes (Tollefson, 2020). Furthermore, understanding impacts of climate change on geomorphic processes requires the use of an emission scenario with a high signal-to-noise ratio in changes of climatic variables because associated uncertainties are large. Even using such a severe emission scenario, the short- and mid-term predictions of sediment fluxes are within the uncertainties estimated for the present climate. This is considering that the total uncertainty could be even higher because we have not included the uncertainties in the emission scenario and in the SedCas model parameters, except for the historical simulation. These results point to the important role of the internal climate variability for the predictions of climate change effects on environmental variables that are characterized by a small signal-to-noise ratio such as precipitation, runoff and sediment yield (see also Coulthard et al., 2012; Addor et al., 2014; Francipane et al., 2015; Pelletier, 2015; Fatichi et al., 2016, for other examples). Accordingly, if internal climate variability, which affects both sediment supply and transport in geomorphic systems, is not considered, then this may lead to an unwarranted overconfidence in the predictions of climate change impacts.

\subsection{SedCas Limitations}

We acknowledge that the simple landslide and debris-flow triggering and spatial lumping in SedCas do not allow us to explore fully the details of sediment erosiondeposition pathways and the timescales of storage (e.g. Lancaster \& Casebeer, 2007; Reid et al., 2007; Fryirs, 2013), debris-flow surges as a result of channel slope variations (Kean et al., 2013), the spatial and temporal variability in sediment sources in the Illgraben (e.g. Berger et al., 2011b; Bennett et al., 2013), the triggering of slope failures by very short (sub-hourly) and intense rainfall events (Coe et al., 2008; Crosta \& Frattini, 2003), the possible blocking of debris flows in the channel system (Otto et al., 2009; Schürch et al., 2011), and other geomorphic processes. Model developments are needed to refine the model's spatial representation to better consider elevation-dependent processes like snow accumulation and melt, include catchment pathway connectivity and also to test other hillslope sediment producing mechanisms. However, the fact that SedCas simulates well the seasonality of the observed debris-flow frequencies and magnitudes (Figure 4), without being explicitly calibrated to do so, gives us confidence in the realism

This article is protected by copyright. All rights reserved. 
of the model and its utility for climate change impact assessment. Furthermore, the simple framework selected for this work enables us to make some inferences about possible changes that are elevation-dependent even without using complex distributed models. More importantly, it allows us to explore uncertainty in a way that would be impossible otherwise.

In this paper we considered landslides to be triggered by frost-weathering. Although we cannot verify the frost-weathering sediment supply mechanism for each individual event, we argue that even rainfall-induced landslides can be limited by frost-weathering as a preparatory factor (e.g. McColl, 2015). Furthermore, there is evidence that seasonal landslide mobilisation is accelerated during the winter and spring seasons when both snowmelt and freezing are the dominant processes in the Illgraben (e.g. Berger et al., 2011b; Bennett et al., 2012, 2013; Caduff et al., 2014). Bennett et al. (2013) found that an increase of erosion rates in the Illgraben coincided with a shift towards shorter snow-covered seasons, indicating that the bedrock was increasingly exposed to weathering and sub-freezing temperatures could propagate deeper into the bedrock. This process is only considered indirectly because the longer sub-freezing temperatures persist while there is little snow cover, the more landslides are triggered. Our temperature threshold is $0^{\circ} \mathrm{C}$ although laboratory investigations of frost-cracking mechanisms suggest that it is most intense when the bedrock temperatures are between -3 and $-8^{\circ} \mathrm{C}$ (Hallet et al., 1991). This outcome has recently been questioned because it has not been tested for different lithologies and frost-cracking can already start at higher temperatures (Draebing \& Krautblatter, 2019). Another related assumption is that the landslide magnitudefrequency distribution in our work is time invariant. The landslide magnitude-frequency distribution statistically describes hillslope failures on the active hillslope over a long period of time (20+ years) and is not expected to change as long as slope gradient or slope morphology do not change significantly.

By also reporting the hypothetical case of supply-unlimited sediment yield, we account for other potential increases in sediment supply which are not simulated in SedCas. First, an exceptionally large landslide, as occurred in 1961, could cause an increase in debris-flow occurrence lasting several years (Hürlimann et al., 2003). Second, forest fires and other vegetation cover reduction could lead to an increase in sediment availability. Although never observed in the catchment, forest fires are predicted to increase in frequency in the Swiss Rhône Valley in the future (Gimmi et al., 2004; Zumbrunnen et al., 2011) and increase sediment availability (e.g. Tillery \& Rengers, 2020; Rengers et al., 2020). Third, the climate simulations show increased drought stress which could damage the vegetation and enhance forest fires (Finsinger \& Tinner, 2007; Zumbrunnen et al., 2011). Although, this could be compensated by reduced frost, changes in species composition and upward treeline shifts (Finsinger \& Tinner, 2007; Rigling et al., 2013; Gehrig-Fasel et al., 2007). Land use changes such as deforestation are not expected for the Illgraben, but should be considered in other catchments.

Despite these limitations, frost-weathering is considered to be a major driver of sediment production in Alpine regions and can be a key control of refilling debris-flow channels between seasons (Matsuoka \& Murton, 2008; Rengers et al., 2020). We expect this to be true for our study area and other Alpine basins as well. Other Alpine sites where the model could potentially be tested are, for example, the Gadria and the Zielbach in the northeastern Italian Alps or the Lattenbach catchment in the western Austrian Alps. They have exceptionally high sediment yields, their elevation range is similar to the Illgraben (Hürlimann et al., 2019; Savi et al., 2014), they are not glaciated and the presence of permafrost is possible only in smaller extents (except for the Zielbach) at the very top of the catchments (Boeckli et al., 2012). To test the generalization of our findings it would be important to apply the presented framework extended to other hillslope sediment producing mechanisms provided they can be formulated and quantified in a probabilistic way.

This article is protected by copyright. All rights reserved. 


\section{Conclusions}

This modelling study quantifies the effect of climate variability and climate change on debris flows and sediment yield in a gemorphologically-active Alpine basin, the Illgraben in Switzerland. We simulate and quantify changes in sediment yield and debris flows due to climate change, and we estimate the inherent uncertainties involved for three future periods: short-term (2035), mid-term (2060) and long-term (2085). The main conclusions can be summarized in four points.

First, the hydrological potential to transport sediment and generate debris flows will increase. If sediment supply to the channel by landslides were unlimited, this would result in an increase in future sediment yield by $23 \%$ in the short term (2035), $31 \%$ in the mid term (2060) and $48 \%$ in the long term (2085).

Second, the role of sediment supply variability by landslides in the context of the sediment cascade model has been highlighted in this work. In a warmer climate, reduced freezing conditions limit frost-weathering, the main mechanism for sediment production and landslide triggering in the Illgraben. Consequently, decreases both in sediment yield $(-23 \%,-22 \%$, and $-48 \%)$ and in the number of debris-flows $(-8 \%,-15 \%$ and $-23 \%)$ are predicted for the short-, mid- and long-term due to more frequent sediment supplylimited conditions.

Third, our findings suggest that climate change impacts on sediment production and yield are elevation dependent. In our analysis, sediment supply decreases at lower $(<2000 \mathrm{~m})$ and increases at higher elevations driven by an increase in exposure of the slope to frost-weathering (more snow free days) despite a reduction in freezing days. This has implications for hazard and risk assessment in a future climate as well as the application of the findings to other catchments.

Fourth, although the same trend is seen for all future periods, at least for the shortterm scenario, predictions are mostly within present-day natural variability. Therefore, it is crucial to consider this internal climate uncertainty in expectations of climate change impacts in geomorphic systems.

Although climate change predictions point to a decrease in the number of debris flows and sediment yield, we showed that the hydrological changes favour sediment transport if enough sediment is available. The occurrence of an exceptionally large landslide, as it happened in the Illgraben in 1961 (Hürlimann et al., 2003), or vegetation cover changes could lead to year-long abundant sediment supply for debris flows. This has potentially severe consequences for the sediment load downstream (e.g. Schlunegger et al., 2009; Berger et al., 2011b). The main uncertainty in our modelling study remains in identifying the triggering of hillslope landslides and debris flows, i.e. the influence of rainfall, soil moisture, snow cover and temperature-driven weathering processes on landslides and debris flows are only accounted for in a conceptual way. Field investigations and monitoring efforts to determine the dominant physical processes behind landslide and debris-flow triggering conditions in Alpine basins remain urgently needed to provide better parameterizations for physically-based and conceptual models. Although the results and conclusions presented here pertain only to the Illgraben, the methodology is expected to be valid for most Alpine geomorphic systems.

\section{Data Availability Statement}

Observed debris-flow volumes are available from the Environmental Data Portal EnviDat (McArdell \& Hirschberg, 2020, http://dx.doi.org/10.16904/envidat.173). Observed climate data and climate scenarios were provided by the Swiss Federal Office of Meteorology (MeteoSwiss) and the National Center for Climate Services (NCCS), respectively, and are available for research purposes.

This article is protected by copyright. All rights reserved. 


\section{Acknowledgments}

This study was funded by the WSL research program Climate Change Impacts on Alpine Mass Movements (CCAMM). We are grateful to E. Leonarduzzi (ETH) and A. Badoux (WSL) for many fruitful discussions, and J. Aaron (ETH) for advice on the SedCas model calibration. We thank B. Fritschi, C. Graf, and S. Boss for technical assistance with the debris-flow data collection. This study benefited from work by B. Lthi conducted in his MSc thesis at ETH Zrich. Finally, the authors wish to thank the Editor (Amy East), Francis Rengers and two anonymous reviewers for their constructive comments which helped to improve the manuscript.

\section{References}

Addor, N., Rössler, O., Köplin, N., Huss, M., Weingartner, R., \& Seibert, J. (2014). Robust changes and sources of uncertainty in the projected hydrological regimes of Swiss catchments. Water Resources Research, 50(10), 7541-7562. doi: 10.1002/2014WR015549

Badoux, A., Graf, C., Rhyner, J., Kuntner, R., \& McArdell, B. W. (2009). A debris-flow alarm system for the Alpine Illgraben catchment: Design and performance. Natural Hazards, 49(3), 517-539. doi: 10.1007/s11069-008-9303-x

Ban, N., Rajczak, J., Schmidli, J., \& Schär, C. (2018). Analysis of Alpine precipitation extremes using generalized extreme value theory in convectionresolving climate simulations. $\quad$ Climate Dynamics, $0(0), 1-15 . \quad$ doi: $10.1007 / \mathrm{s} 00382-018-4339-4$

Ban, N., Schmidli, J., \& Schär, C. (2015). Heavy precipitation in a changing climate: Does short-term summer precipitation increase faster? Geophysical Research Letters, 42(4), 1165-1172. doi: 10.1002/2014GL062588

Bardou, E., \& Delaloye, R. (2004). Effects of ground freezing and snow avalanche deposits on debris flows in alpine environments. Natural Hazards and Earth System Science, 4(4), 519-530. doi: 10.5194/nhess-4-519-2004

Battista, G., Schlunegger, F., Burlando, P., \& Molnar, P. (2020). Modelling localized sources of sediment in mountain catchments for provenance studies. Earth Surface Processes and Landforms. doi: 10.1002/esp.4979

Benda, L., \& Dunne, T. (1997a). Stochastic forcing of sediment routing and storage in channel networks. Water Resources Research, 33(12), 2865-2880. doi: 10 $.1029 / 97 \mathrm{WR} 02387$

Benda, L., \& Dunne, T. (1997b). Stochastic forcing of sediment supply to channel networks from landsliding and debris flow. Water Resources Research, 33(12), 2849-2863. doi: 10.1029/97WR02388

Bennett, G. L., Molnar, P., Eisenbeiss, H., \& Mcardell, B. W. $\quad$ (2012). Erosional power in the Swiss Alps: Characterization of slope failure in the Illgraben. $\quad$ Earth Surface Processes and Landforms, 37(15), 1627-1640. doi: 10.1002/esp.3263

Bennett, G. L., Molnar, P., McArdell, B. W., \& Burlando, P. (2014). A probabilistic sediment cascade model of sediment transfer in the Illgraben. Water Resources Research, 50(2), 1225-1244. doi: 10.1002/2013WR013806

Bennett, G. L., Molnar, P., McArdell, B. W., Schlunegger, F., \& Burlando, P. (2013). Patterns and controls of sediment production, transfer and yield in the Illgraben. Geomorphology, 188, 68-82. doi: 10.1016/j.geomorph.2012.11.029

Berger, C., McArdell, B. W., \& Schlunegger, F. (2011a). Direct measurement of channel erosion by debris flows, Illgraben, Switzerland. Journal of Geophysical Research: Earth Surface, 116(1), 1-18. doi: 10.1029/2010JF001722

Berger, C., McArdell, B. W., \& Schlunegger, F. (2011b). Sediment transfer patterns at the Illgraben catchment, Switzerland: Implications for the time scales of debris flow activities. Geomorphology, 125(3), 421-432. doi: 10.1016/j.geomorph.2010.10.019

This article is protected by copyright. All rights reserved. 
Beven, K. (1993). Prophecy, reality and uncertainty in distributed hydrological modellingle. Advances in Water Resources, 16(1), 41-51.

Beven, K., \& Freer, J. (2001). Equifinality, data assimilation, and uncertainty estimation in mechanistic modelling of complex environmental systems using the GLUE methodology. Journal of Hydrology, 249(1-4), 11-29. doi: 10.1016/S0022-1694(01)00421-8

Boeckli, L., Brenning, A., Gruber, A., \& Noetzli, J. (2012). Alpine permafrost index map [data set]. PANGAEA. doi: 10.1594/PANGAEA.784450

Brutsaert, W. (2005). Hydrology: an introduction. Cambridge University Press.

Caduff, R., Kos, A., Schlunegger, F., McArdell, B. W., \& Wiesmann, A.

(2014). Terrestrial radar interferometric measurement of hillslope deformation and atmospheric disturbances in the Illgraben debris-flow catchment, Switzerland. IEEE Geoscience and Remote Sensing Letters, 11(2), 434-438. doi: 10.1109/LGRS.2013.2264564

Campforts, B., Vanacker, V., Herman, F., Vanmaercke, M., Schwanghart, W., Tenorio, G. E., ... Govers, G. (2020). Parameterization of river incision models requires accounting for environmental heterogeneity: insights from the tropical Andes. Earth Surface Dynamics, 8(2), 447-470. Retrieved from https://www.earth-surf-dynam.net/8/447/2020/ doi: $10.5194 /$ esurf-8-447-2020

CH2018. (2018). CH2018 Climate Scenarios for Switzerland, Technical Report, National Centre for Climate Services, Zurich (Tech. Rep.).

Coe, J. A., Bessette-Kirton, E. K., \& Geertsema, M. (2018). Increasing rockavalanche size and mobility in Glacier Bay National Park and Preserve, Alaska detected from 1984 to 2016 Landsat imagery. Landslides, 15(3), 393-407. doi: 10.1007/s10346-017-0879-7

Coe, J. A., Kinner, D. A., \& Godt, J. W. (2008). Initiation conditions for debris flows generated by runoff at Chalk Cliffs, central Colorado. Geomorphology, 96(3-4), 270-297. doi: 10.1016/j.geomorph.2007.03.017

Copernicus Climate Change Service (C3S). (2017). ERA5: Fifth generation of ECMWF atmospheric reanalyses of the global climate.

Coulthard, T. J., Ramirez, J., Fowler, H. J., \& Glenis, V. (2012). Using the UKCP09 probabilistic scenarios to model the amplified impact of climate change on drainage basin sediment yield. Hydrology and Earth System Sciences, 16 (11), 4401-4416. doi: 10.5194/hess-16-4401-2012

Coulthard, T. J., \& Skinner, C. J. (2016). The sensitivity of landscape evolution models to spatial and temporal rainfall resolution. Earth Surface Dynamics, 4(3), 757-771. doi: 10.5194/esurf-4-757-2016

Coulthard, T. J., \& Van De Wiel, M. J. (2013). Climate, tectonics or morphology: What signals can we see in drainage basin sediment yields? Earth Surface Dynamics, 1(1), 13-27. doi: 10.5194/esurf-1-13-2013

Coulthard, T. J., \& Van De Wiel, M. J. (2017). Modelling long term basin scale sediment connectivity, driven by spatial land use changes. Geomorphology, 277, 265-281. Retrieved from http://dx.doi.org/10.1016/j.geomorph.2016.05 .027 doi: $10.1016 /$ j.geomorph.2016.05.027

Crosta, G. B., \& Frattini, P. (2003). Distributed modelling of shallow landslides triggered by intense rainfall. Natural Hazards and Earth System Science, 3(1/2), 81-93. doi: 10.5194/nhess-3-81-2003

de Haas, T., Nijland, W., de Jong, S. M., \& Mcardell, B. W. (2020). How memory effects, check dams, and channel geometry control erosion and deposition by debris flows. Scientific Reports(0123456789), 1-8. Retrieved from https:// doi.org/10.1038/s41598-020-71016-8 doi: 10.1038/s41598-020-71016-8

Deser, C., Phillips, A., Bourdette, V., \& Teng, H. (2012). Uncertainty in climate change projections: The role of internal variability. Climate Dynamics, 38(34), 527-546. doi: 10.1007/s00382-010-0977-x

This article is protected by copyright. All rights reserved. 
Draebing, D., \& Krautblatter, M. (2019). The Efficacy of Frost Weathering Processes in Alpine Rockwalls. Geophysical Research Letters, 46(12), 6516-6524. doi: 10.1029/2019GL081981

Fatichi, S., Ivanov, V. Y., \& Caporali, E. (2011). Simulation of future climate scenarios with a weather generator. Advances in Water Resources, 34(4), 448-467. doi: 10.1016/j.advwatres.2010.12.013

Fatichi, S., Ivanov, V. Y., \& Caporali, E. (2013). Assessment of a stochastic downscaling methodology in generating an ensemble of hourly future climate time series. Climate Dynamics, 40(7-8), 1841-1861. doi: 10.1007/s00382-012-1627-2

Fatichi, S., Ivanov, V. Y., Paschalis, A., Peleg, N., Molnar, P., Rimkus, S., ... Caporali, E. (2016). Uncertainty partition challenges the predictability of vital details of climate change. Earth's Future, 4(5), 240-251. doi: 10.1002/2015EF000336

Fernandez Luque, R., \& Van Beek, R. (1976). Erosion and transport of bed-load sediment. Journal of hydraulic research, 14(2), 127-144.

Finsinger, W., \& Tinner, W. (2007). Pollen and plant macrofossils at Lac de Fully (2135 m a.s.l.): Holocene forest dynamics on a highland plateau in the Valais, Switzerland. Holocene, 17(8), 1119-1127. doi: 10.1177/0959683607082552

Fischer, L., Huggel, C., Kääb, A., \& Haeberli, W. (2013). Slope failures and erosion rates on a glacierized high-mountain face under climatic changes. Earth Surface Processes and Landforms, 38(8), 836-846. doi: 10.1002/esp.3355

Francipane, A., Fatichi, S., Ivanov, V. Y., \& Noto, L. V. (2015). Stochastic assessment of climate impacts on hydrology and geomorphology of semiarid headwater basins using a physically based model. Journal of Geophysical Research F: Earth Surface, 120(3), 507-533. doi: 10.1002/2014JF003232

Franke, D., Hornung, J., \& Hinderer, M. ～(2015). ～A combined study of radar facies, lithofacies and three-dimensional architecture of an alpine alluvial fan (Illgraben fan, Switzerland). $\quad$ Sedimentology, 62(1), 57-86. doi: $10.1111 /$ sed.12139

Fryirs, K. (2013). (Dis)Connectivity in catchment sediment cascades: A fresh look at the sediment delivery problem. Earth Surface Processes and Landforms, 38(1), 30-46. doi: 10.1002/esp.3242

Gariano, S. L., \& Guzzetti, F. (2016). Landslides in a changing climate. EarthScience Reviews, 162, 227-252. Retrieved from http://dx.doi.org/10.1016/ j.earscirev.2016.08.011 doi: 10.1016/j.earscirev.2016.08.011

Gehrig-Fasel, J., Guisan, A., \& Zimmermann, N. E. (2007). Tree line shifts in the Swiss Alps: Climate change or land abandonment? Journal of Vegetation Science, 18(4), 571-582. Retrieved from https://onlinelibrary.wiley.com/ doi/abs/10.1111/j.1654-1103.2007.tb02571.x doi: 10.1111/j.1654-1103 .2007.tb02571.x

Gimmi, U., Bürgi, M., \& Wohlgemuth, T. (2004). Wie oft brannte der Walliser Wald im 20. Jahrhundert? - Forest fire occurrences in Canton Valais in the 20th century. Schweizerische Zeitschrift fur Forstwesen, 155(10), 437-440.

Giorgi, F., Torma, C., Coppola, E., Ban, N., Schär, C., \& Somot, S. (2016). Enhanced summer convective rainfall at Alpine high elevations in response to climate warming. Nature Geoscience, 9(8), 584-589. doi: 10.1038/ngeo2761

Hallet, B., Walder, J. S., \& Stubbs, C. W. (1991). Weathering by segregation ice growth in microcracks at sustained subzero temperatures: Verification from an experimental study using acoustic emissions. Permafrost and Periglacial Processes, 2(4), 283-300. doi: 10.1002/ppp.3430020404

Hancock, G. R., Coulthard, T. J., \& Lowry, J. B. (2016). Predicting uncertainty in sediment transport and landscape evolution - the influence of initial surface conditions. Computers and Geosciences, 90, 117-130. Retrieved from http://dx.doi.org/10.1016/j.cageo.2015.08.014 doi:

This article is protected by copyright. All rights reserved. 
10.1016/j.cageo.2015.08.014

Harris, C., Arenson, L. U., Christiansen, H. H., Etzelmüller, B., Frauenfelder, R., Gruber, S., .. Vonder Mühll, D. (2009). Permafrost and climate in Europe: Monitoring and modelling thermal, geomorphological and geotechnical responses. Earth-Science Reviews, 92(3-4), 117-171. doi: 10.1016/j.earscirev.2008.12.002

Hawkins, E., \& Sutton, R. (2009). The potential to narrow uncertainty in regional climate predictions. Bulletin of the American Meteorological Society, 90(8), 1095-1107. doi: 10.1175/2009BAMS2607.1

Hersbach, H., de Rosnay, P., Bell, B., Schepers, D., Simmons, A., Soci, C., ... Zuo, H. (2018). Operational global reanalysis: progress, future directions and synergies with NWP. (27). doi: 10.21957/tkic6g3wm

Hürlimann, M., Coviello, V., Bel, C., Guo, X., Berti, M., Graf, C., ... Yin, H. Y. (2019). Debris-flow monitoring and warning: Review and examples. EarthScience Reviews, 199 (May), 102981. doi: 10.1016/j.earscirev.2019.102981

Hürlimann, M., Rickenmann, D., \& Graf, C. (2003). Field and monitoring data of debris-flow events in the Swiss Alps. Canadian Geotechnical Journal, 40(1), 161-175. doi: 10.1139/t02-087

Hydrological Atlas of Switzerland. (2015). Retrieved 2020-09-04, from https:// hydrologicalatlas.ch

IPCC. (2012). Managing the risks of extreme events and disasters to advance climate change ad- aptation. A special report of working groups I and II of the intergovernmental panel on climate change. Cambridge University Press. Retrieved from http://elibrary.worldbank.org/doi/book/10.1596/ 978-0-8213-8845-7 doi: 10.1596/978-0-8213-8845-7

Istanbulluoglu, E. (2009). Modeling catchment evolution: From decoding geomorphic processes signatures toward predicting impacts of climate change. Geography Compass, 3(3), 1125-1150. doi: 10.1111/j.1749-8198.2009.00228.x

Jomelli, V., Brunstein, D., Déqué, M., Vrac, M., \& Grancher, D. (2009). Impacts of future climatic change (2070-2099) on the potential occurrence of debris flows: A case study in the Massif des Ecrins (French Alps). Climatic Change, 97(1), 171-191. doi: 10.1007/s10584-009-9616-0

Jomelli, V., Pech, V. P., Chochillon, C., \& Brunstein, D. (2004). Geomorphic variations of debris flows and recent climatic change in the French Alps. Climatic Change, 64(1-2), 77-102. doi: 10.1023/B:CLIM.0000024700.35154.44

Kean, J. W., McCoy, S. W., Tucker, G. E., Staley, D. M., \& Coe, J. A. Runoff-generated debris flows: Observations and modeling of surge initiation, magnitude, and frequency. Journal of Geophysical Research: Earth Surface, 118(4), 2190-2207. doi: 10.1002/jgrf.20148

Kim, J., Ivanov, V. Y., \& Fatichi, S. (2016a). Climate change and uncertainty assessment over a hydroclimatic transect of Michigan. Stochastic Environmental Research and Risk Assessment, 30(3), 923-944. doi: 10.1007/s00477-015-1097 $-2$

Kim, J., Ivanov, V. Y., \& Fatichi, S. (2016b). Environmental stochasticity controls soil erosion variability. Scientific Reports, 6(February), 1-7. doi: 10.1038/ srep22065

Lancaster, S. T., \& Casebeer, N. E. (2007). Sediment storage and evacuation in headwater valleys at the transition between debris-flow and fluvial processes. Geology, 35(11), 1027-1030. doi: 10.1130/G239365A.1

Lehner, F., Deser, C., Maher, N., Marotzke, J., Fischer, E., Brunner, L., ... Hawkins, E. (2020). Partitioning climate projection uncertainty with multiple Large Ensembles and CMIP5/6. Earth System Dynamics Discussions, 1-28. doi: 10.5194/esd-2019-93

Lu, H., Moran, C. J., \& Sivapalan, M. (2005). A theoretical exploration of catchment-scale sediment delivery. Water Resources Research, 41(9), 1-15.

This article is protected by copyright. All rights reserved. 
doi: $10.1029 / 2005 W R 004018$

Matsuoka, N., \& Murton, J. (2008). Surface Energy Fluxes and DistributionModels of Permafrost in European Mountain Areas: an Overview of Current Developments. Permafrost and Periglacial Processes, 19(January), 195-210. doi: $10.1002 / \mathrm{ppp}$

McArdell, B. W., Bartelt, P., \& Kowalski, J. (2007). Field observations of basal forces and fluid pore pressure in a debris flow. Geophysical Research Letters, 34 (7), 2-5. doi: 10.1029/2006GL029183

McArdell, B. W., \& Hirschberg, J. (2020). Debris-flow volumes at the Illgraben 2000-2017. EnviDat. Retrieved from https://www.envidat.ch/ dataset/debris-flow-volumes-at-the-illgraben-2000-2017 doi: http://dx.doi.org/10.16904/envidat.173

McColl, S. T. (2015). Chapter 2 - Landslide Causes and Triggers. In J. F. Shroder \& T. Davies (Eds.), Landslide hazards, risks and disasters (pp. 17-42). Boston: Academic Press. Retrieved from http://www.sciencedirect.com/science/ article/pii/B9780123964526000021 doi: https://doi.org/10.1016/B978-0-12 $-396452-6.00002-1$

Meyer-Peter, E., \& Müller, R. (1948). Formulas for bed-load tranport. In Iahsr 2nd meeting, stockholm, appendix 2. IAHR.

Molnar, P., Burlando, P., Kirsch, J., \& Hinz, E. (2006). Model investigations of the effects of land-use changes and forest damage on erosion in mountainous environments. Sediment Dynamics and the Hydromorphology of Fluvial Systems, 306 (July), 589-600.

Morris, G. L., Annandale, G., \& Hotchkiss, R. (2008). Reservoir sedimentation. In Sedimentation engineering: processes, measurements, modeling, and practice (pp. 579-612).

Moss, R. H., Edmonds, J. A., Hibbard, K. A., Manning, M. R., Rose, S. K., Van Vuuren, D. P., ... Wilbanks, T. J. (2010). The next generation of scenarios for climate change research and assessment. Nature, 463(7282), 747-756. doi: $10.1038 /$ nature 08823

Mullan, D., Favis-Mortlock, D., \& Fealy, R. ～(2012). Addressing key limitations associated with modelling soil erosion under the impacts of future climate change. Agricultural and Forest Meteorology, 156, 18-30. Retrieved from http://dx.doi.org/10.1016/j.agrformet.2011.12.004 doi: 10.1016/j.agrformet.2011.12.004

Otto, J.-C., Schrott, L., Jaboyedoff, M., \& Dikau, R. (2009). Quantifying sediment storage in a high alpine valley (Turtmanntal, Switzerland). Earth Surface Processes and Landforms, 34(March), 1726-1742. doi: 10.1002/ esp.1856Quantifying

Peizhen, Z., Molnar, P., \& Downs, W. R. (2001). Increased sedimentation rates and grain sizes 2-4 Myr ago due to the influence of climate change on erosion rates. Nature, 410(6831), 891-897. doi: 10.1038/35073504

Peleg, N., Molnar, P., Burlando, P., \& Fatichi, S. (2019). Exploring stochastic climate uncertainty in space and time using a gridded hourly weather generator. Journal of Hydrology, 571(August 2018), 627-641. Retrieved from https://doi.org/10.1016/j.jhydrol.2019.02.010 doi: 10.1016/j.jhydrol.2019.02.010

Peleg, N., Sinclair, S., Fatichi, S., \& Burlando, P. (2020). Downscaling climate projections over large and data sparse regions: Methodological application in the Zambezi River Basin. International Journal of Climatology(March), 1-23. doi: 10.1002/joc.6578

Peleg, N., Skinner, C., Fatichi, S., \& Molnar, P. (2020). Temperature effects on the spatial structure of heavy rainfall modify catchment hydro-morphological response. Earth Surface Dynamics, 8(1), 17-36. doi: 10.5194/esurf-8-17-2020

This article is protected by copyright. All rights reserved. 
Pelletier, J. D. A. B. (2015). Forecasting response. Proceedings of the Intersociety Energy Conversion Engineering Conference, 3, 352-357. doi: 10.1002/ 2014EF000290.Received

Perron, J. T. (2017). Climate and the Pace of Erosional Landscape Evolution. Annual Review of Earth and Planetary Sciences, 45(1), 561-591. doi: 10.1146/ annurev-earth-060614-105405

Phillips, J. (2003). Alluvial storage and the long-term stability of sediment yields. Basin Research, 15(2), 153-163. doi: 10.1046/j.1365-2117.2003.00204.x

Priestley, C. H. B., \& Taylor, R. J. (1972). On the Assessment of Surface Heat Flux and Evaporation Using Large-Scale Parameters. Monthly Weather Review, 100(2), 81-92.

Rajczak, J., Pall, P., \& Schär, C. (2013). Projections of extreme precipitation events in regional climate simulations for Europe and the Alpine Region. Journal of Geophysical Research: Atmospheres, 118(9), 3610-3626. doi: 10.1002/jgrd.50297

Reid, S. C., Lane, S. N., Montgomery, D. R., \& Brookes, C. J. （2007). Does hydrological connectivity improve modelling of coarse sediment delivery in upland environments? Geomorphology, 90(3-4), 263-282. doi: 10.1016/j.geomorph.2006.10.023

Rengers, F., Kean, J. W., Reitman, N. G., Smith, J. B., Coe, J. A., \& McGuire, L. A. (2020). The Influence of Frost Weathering on Debris Flow Sediment Supply in an Alpine Basin. Journal of Geophysical Research: Earth Surface. doi: 10.1029/2019jf005369

Riahi, K., Rao, S., Krey, V., Cho, C., Chirkov, V., Fischer, G., .. Rafaj, P. (2011). RCP 8.5-A scenario of comparatively high greenhouse gas emissions. Climatic Change, 109(1), 33-57. doi: 10.1007/s10584-011-0149-y

Rigling, A., Bigler, C., Eilmann, B., Feldmeyer-Christe, E., Gimmi, U., Ginzler, C., ... Others (2013). Driving factors of a vegetation shift from Scots pine to pubescent oak in dry Alpine forests. Global Change Biology, 19(1), 229-240.

Saltelli, A., Ratto, M., Andres, T., Campolongo, F., Cariboni, J., Gatelli, D., ... Tarantola, S. (2008). Global Sensitivity Analysis. The Primer. doi: $10.1002 / 9780470725184$

Savi, S., Norton, K. P., Picotti, V., Akçar, N., Delunel, R., Brardinoni, F., ... Schlunegger, F. (2014). Quantifying sediment supply at the end of the last glaciation: Dynamic reconstruction of an alpine debris-flow fan. Bulletin of the Geological Society of America, 126(5-6), 773-790. doi: 10.1130/B30849.1

Schlunegger, F., Badoux, A., McArdell, B. W., Gwerder, C., Schnydrig, D., RiekeZapp, D., \& Molnar, P. (2009). Limits of sediment transfer in an alpine debris-flow catchment, Illgraben, Switzerland. Quaternary Science Reviews, 28(11-12), 1097-1105. Retrieved from http://dx.doi.org/10.1016/ j.quascirev.2008.10.025 doi: 10.1016/j.quascirev.2008.10.025

Schürch, P., Densmore, A. L., Rosser, N. J., \& McArdell, B. W. (2011). Dynamic controls on erosion and deposition on debris-flow fans. Geology, 39(9), 827830. doi: $10.1130 / \mathrm{G} 32103.1$

Shrestha, N. K., \& Wang, J. (2018). Predicting sediment yield and transport dynamics of a cold climate region watershed in changing climate. Science of the Total Environment, 625, 1030-1045. doi: 10.1016/j.scitotenv.2017.12.347

Skinner, C. J., Coulthard, T. J., Schwanghart, W., Van De Wiel, M. J., \& Hancock, G. (2018). Global sensitivity analysis of parameter uncertainty in landscape evolution models. Geoscientific Model Development, 11(12), 4873-4888. doi: 10.5194/gmd-11-4873-2018

Sobol, I. M. (1976). Uniformly distributed sequences with an additional uniform property. USSR Computational Mathematics and Mathematical Physics, 16(5), 236-242. doi: 10.1016/0041-5553(76)90154-3

This article is protected by copyright. All rights reserved. 


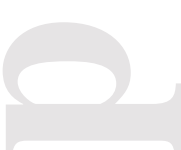

This article is protected by copyright. All rights reserved. matic Change, 122(1-2), 141-155. doi: 10.1007/s10584-013-0993-z 69(1-2), 48-58. doi: 10.1016/j.gloplacha.2009.08.001 $10.1002 /$ esp.4761 244-260. doi: 10.1002/hyp.13321 doi: 10.1007/s10584-016-1657-6 draulics division, 92(6), 49-59. 8861. doi: $10.1029 / 2019 \mathrm{gl} 083874$ ment, 261 (12), 2188-2199.

Stoffel, M., Mendlik, T., Schneuwly-Bollschweiler, M., \& Gobiet, A. (2014). Possible impacts of climate change on debris-flow activity in the Swiss Alps. Cli-

Temme, A. J., Baartman, J. E., \& Schoorl, J. M. (2009). Can uncertain landscape evolution models discriminate between landscape responses to stable and changing future climate? A millennial-scale test. Global and Planetary Change,

Tillery, A. C., \& Rengers, F. K. (2020). Controls on debris-flow initiation on burned and unburned hillslopes during an exceptional rainstorm in southern New Mexico, USA. Earth Surface Processes and Landforms, 45(4), 1051-1066. doi:

Tollefson, J. (2020). How hot will Earth get by 2100? Nature, 580(7804), 443-445.

Tsuruta, K., Hassan, M. A., Donner, S. D., \& Alila, Y. (2019). Modelling the effects of climatic and hydrological regime changes on the sediment dynamics of the Fraser River Basin, British Columbia, Canada. Hydrological Processes, 33(2),

Tucker, G. E., \& Slingerland, R. (1997). Drainage basin responses to climate change. Water Resources Research, 33(8), 2031-2047. doi: 10.1029/97WR00409

Turkington, T., Remaître, A., Ettema, J., Hussin, H., \& van Westen, C. (2016). Assessing debris flow activity in a changing climate. Climatic Change, 137(1-2), 293-305. Retrieved from http://dx.doi.org/10.1007/s10584-016-1657-6

Wilson, K. C. (1966). Bed-load transport at high shear stress. Journal of the hy-

Yetemen, O., Saco, P. M., \& Istanbulluoglu, E. (2019). Ecohydrology controls the geomorphic response to climate change. Geophysical Research Letters, 8852-

Zumbrunnen, T., Pezzatti, G. B., Menéndez, P., Bugmann, H., Bürgi, M., \& Conedera, M. (2011). Weather and human impacts on forest fires: 100 years of fire history in two climatic regions of Switzerland. Forest Ecology and Manage- 